Discussion Paper No. 08-115

The Effect of Early Noncognitive Skills on Social Outcomes in Adolescence

Katja Coneus and Manfred Laucht

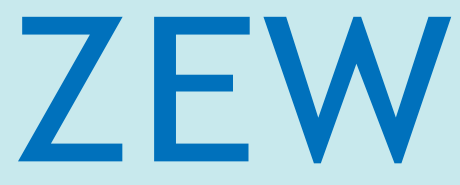

Zentrum für Europäische Wirtschaftsforschung $\mathrm{GmbH}$

Centre for European

Economic Research 
Discussion Paper No. 08-115

\title{
The Effect of Early Noncognitive Skills on Social Outcomes in Adolescence
}

\author{
Katja Coneus and Manfred Laucht
}

Download this ZEW Discussion Paper from our ftp server:

ftp://ftp.zew.de/pub/zew-docs/dp/dp08115.pdf

Die Discussion Papers dienen einer möglichst schnellen Verbreitung von neueren Forschungsarbeiten des ZEW. Die Beiträge liegen in alleiniger Verantwortung der Autoren und stellen nicht notwendigerweise die Meinung des ZEW dar.

Discussion Papers are intended to make results of ZEW research promptly available to other economists in order to encourage discussion and suggestions for revisions. The authors are solely responsible for the contents which do not necessarily represent the opinion of the ZEW. 


\section{Non-technical summary}

In this study we investigate the impact of early noncognitive skills on several outcomes during adolescence which are important for both educational and labour market success. Although noncognitive skills remain malleable until adulthood, their fundamental elements are created during early childhood.

Our empirical analysis is based on the Mannheim Study of Children at Risk, an epidemiological cohort study which observes children from birth until adulthood. We analyse how noncognitive skills, developed during the first two years of life, influence an adolescent's educational success, delinquent behaviour, health risk behaviour and autonomy. The four non-cognitive skills considered in this study are: attention span, approach, prevailing mood and distractability.

According to the results, a child's attention span and his approach are crucial noncognitive skills with a long-term impact on observable outcomes during adolescence. Children with a clear interest in new things and children with a high attention span during early childhood do much better in terms of educational success, autonomy and health risk behaviour during adolescence.

Contrary to this, we find that a prevailing bad temper and a high distractability during early childhood only negatively impact the performance and behaviour of those adolescents with extremely low non-cognitive skills.

Moreover, gender differences can be observed between boys and girls with identical noncognitive skills. Boys are less successful in school than girls, their tobacco and alcohol consumption is significantly higher and they are less independent during adolescence.

Our analysis shows that the most important risk group is made up of children with low noncognitive skills who were born with organic or psychosocial risks. The school achievements of children whose birth weight was low are significantly lower than those of other children with the same noncognitive skills during early childhood. Children who are raised by single parents or whose parents are less educated or delinquent consume much more alcohol during adolescence and are clearly more likely to become delinquent themselves.

Thus, our economic analysis underlines the importance of early childhood with regard to a number of social outcomes during adolescence. It is the first of its kind to focus on noncognitive skills. 


\section{Das Wichtigste in Kürze}

In dieser Untersuchung betrachten wir den Einfluss frühkindlicher nicht-kognitiver Fähigkeiten für eine Reihe von Faktoren im Jugendalter, welche sowohl für den Bildungs- als auch für den späteren Arbeitsmarkterfolg von Bedeutung sind. Zwar sind nicht-kognitive Fähigkeiten im Gegensatz zu kognitiven Fähigkeiten bis ins Erwachsenenalter beeinflussbar, allerdings werden die Grundlagen bereits in den ersten Lebensjahren gebildet.

Wir untersuchen auf Basis der Mannheimer Risikokinderstudie, eine psychologische Längsschnittstudie, die Kinder von der Geburt bis ins Erwachsenenalter hinein beobachtet, wie nicht-kognitive Fähigkeiten in den ersten zwei Lebensjahren die Schulleistungen, die Kriminalität, gesundheitliches Risikoverhalten und die Selbständigkeit im Jugendalter beeinflussen. Betrachtet werden folgende vier nichtkognitive Fähigkeiten: die Aufmerksamkeitsspanne, das Kontaktverhalten, die Emotionalität und die Anpassung an Stress.

Die Ergebnisse zeigen, dass insbesondere die Aufmerksamkeit und das Kontaktverhalten zentrale nicht-kognitive Fähigkeiten sind, die langfristig Einfluss auf beobachtbare Faktoren im Jugendalter haben. Aufgeschlossene Kinder und Kinder mit einer hohen Aufmerksamkeit erzielen im Jugendalter deutlich bessere Schulleistungen, sind selbständiger und verhalten sich gesundheitsbewusster.

Im Gegensatz dazu finden wir, dass bei der Emotionalität und der Anpassung an Stress nur die Kinder im Jugendalter benachteiligt sind, die sehr geringe nicht-kognitive Fähigkeiten haben.

Darüber hinaus finden wir, dass Jungen im Vergleich zu Mädchen mit identischen nicht-kognitiven Fähigkeiten, schlechtere Schulleistungen haben, signifikant öfter Rauchen und Alkohol trinken und darüber hinaus weniger selbständig sind.

In unserer Analyse sind gerade die Kinder benachteiligt, die neben geringen nichtkognitiven Fähigkeiten zudem entweder mit organischen oder psychosozialen Risiko geboren wurden. Bei gleichen nicht-kognitiven Fähigkeiten haben Kinder mit geringem Geburtsgewicht deutlich schlechtere Schulleistungen. Dagegen haben Kinder, deren Eltern ein geringes Bildungsniveau haben, Alleinerziehend sind oder gar kriminell, bei gleichen nicht-kognitiven Fähigkeiten einen deutlich höheren Alkoholkonsum und eine höhere Wahrscheinlichkeit selbst kriminell zu werden.

Diese ökonomische Analyse unterstreicht damit die Bedeutung der frühen Kindheit im Lebenszyklus für eine Vielzahl von Erfolgsgrößen im Jugendalter, erstmals aus der Perspektive nicht-kognitiver Fähigkeiten. 


\title{
The Effect of Early Noncognitive Skills on Social Outcomes in Adolescence
}

\author{
Katja Coneus*, Manfred Laucht ${ }^{\dagger}$
}

December 11, 2008

\begin{abstract}
This paper investigates the impact of early noncognitive skills on social outcomes in adolescence. The child's attention span, approach, prevailing mood and distractibility in early childhood may be crucial predictors for school achievements, health risk behavior, delinquency and autonomy as adolescent. We investigate this issue using a longitudinal epidemiological cohort study of 384 children at risk from the Rhine-Neckar Region in Germany. Our results indicate that noncognitive skills in early childhood are important predictors of educational success, tobacco and alcohol use, delinquency and autonomy in adolescence. In particular, the attention span has emerged as a dominant factor among noncognitive skills regarding educational performance, health behavior and delinquency in our study. Further, we find that boys with low noncognitive skills have significantly lower social outcomes compared to girls.
\end{abstract}

Keywords: noncognitive skills, early childhood, risk factors, social outcomes JEL-classification: I20, J13, J24

Acknowledgements: We gratefully acknowledge support from the Leibniz Association, Bonn under grant "Noncognitive Skills: Acquisition and Economic Consequences". Manfred Laucht thanks the German Research Foundation and the Ministry of Science and Research for their support in conducting MARS. For helpful discussions we thank Andrea Mühlenweg, Maresa Sprietsma and Francois Lainey. All remaining errors are ours.

\footnotetext{
${ }^{*}$ Centre for European Economic Research, Mannheim.

${ }^{\dagger}$ Research Group Neuropsychology of Childhood and Adolescence at ZI, Mannheim.
} 


\section{Introduction}

Differences in a child's noncognitive skills become already apparent at birth. A few years ago it was still assumed that noncognitive skills were mainly driven by biological endowment. However, the traditional assumption that genetic influences are most pronounced in early life has proven incorrect. Recent research findings by psychologists have shown that children are born with self-organized incentive-response systems, which adapt during their development. Individuals begin at different starting points with the reactivity within these systems (Kagan and Snideman; 2004). These starting points differ due to variations in genotype and variations in the prenatal environment. Thus, noncognitive skills are partly heritable but change in interaction with a child's environment.

However, although noncognitive skills are more malleable over the whole life cycle than cognitive skills, the stock of noncognitive skills which was built in early childhood increases monotonically from early childhood to adulthood. Different noncognitive skills develop over the life cycle, but to different extents and at different stages in life. Therefore, some noncognitive skills are relatively stable in childhood such as conscientiousness, while others reach only stability in late adulthood. For example, inhibited toddlers are unlikely to become exuberant children (Kagan and Snideman; 1999). Thus, the early years lay the foundation for the acquisition of noncognitive skills over the life cycle, see for example Heckman et al. (2006) and Borghans et al. (2008).

Understanding the effects of early noncognitive skill formation has important implications in terms of educational policy. In recent years a number of economic studies have demonstrated the importance of noncognitive skills for school as well as for labor market success, for example, the studies by Bowles et al. (2001), Duncan et al. (2001), Claessens et al. (2006), Carneiro et al. (2008) or Heckman et al. (2006). Duckworth and Seligman (2005) examined the role of noncognitive skills in improving educational attainment, showing that self-discipline outdoes IQ as a predictor for final grades. The study by Duncan et al. (2007) focused on school readiness at school entry and on later school achievements. Besides math and reading (cognitive skills), the authors find that attention skills are the best predictors for educational attainment. This result is based on six different longitudinal studies of children in the US, UK and Canada. Seminal work by 
Martin et al. (1994) even found that the different dimensions of temperament are five times better predictors for school success than a persons's IQ.

Apart from economic returns on noncognitive skills in terms of school achievements and wages, there might be additional noneconomic returns on noncognitive skills. These returns may come from healthier behavior, reduced criminality and greater subjective well-being, compare Shiner and Caspi (2003). Heckman et al. (2006), for example, examined the effect of noncognitive skills on a wide variety of risk behaviors. They conclude that noncognitive skills strongly influence tobacco and marihuana use as well as delinquency in adolescence. The study by Shirley et al. (2000) suggests that, beyond adverse family and genetic effects, a high extraversion in childhood predicts an earlier onset of alcohol consumption. Besides school and family effects, the individual's ability to build good peer contacts protects against criminality. Gordon (1993) reports a relationship between attention-deficit hyperactivity disorder (ADHD) in childhood and delinquent behavior in adolescence. The study of Shiner et al. (2003) who tracked children aged 8 to 12 years until adulthood reveals that four traits of childhood personality, including motivation (which is related to attention skills), conscientiousness, surgency (which is related to the initial reaction) and agreeableness (which is related to mood) predict adult autonomy two decades later. In addition, the study of Deal et al. (2005) found that the temperament in early and middle childhood accounted for an average of $32 \%$ of the variance in personality in late adolescence and early adulthood.

Our paper expends on the results of previous work in the following ways: First, in this paper we use a longitudinal data set to investigate the effect of early noncognitive skills at the age between three months and two years on educational performance (grades in math and German), health risk behavior (tobacco and alcohol use), juvenile delinquency and autonomy in adolescence. We use four different dimensions of the child's temperament as noncognitive skills in early childhood, attention span, approach, prevailing mood and distractibility. Our empirical analysis is based on the Mannheim Study of Children at Risk, which follows individuals from birth until adolescence. The study is called "at risk" because children suffering from organic or psychosocial risks at birth are oversampled. Derived from the design of the study we can separate the children into 
three different samples; the organic risk sample; the psychosocial risk sample and a "representative" sample (for a detailed explanation, see section 2). The data provides detailed psychometric assessments as well as medical and psychological expert ratings for a child's noncognitive skills. Tracking children from early childhood until adolescence provides longer term evidence, including educational achievements, health risk behavior, delinquency and autonomy.

Second, we analyse the influence of each noncognitive skill on each social outcome, taking into account a nonlinear association between early noncognitive skills and social outcomes. Due to the fact that unobserved time-invariant factors may influence both early noncognitive skills and social outcomes, we estimate time fixed effect (FE) models on a child level. We calculated models for five different samples, OLS using the total sample, FE using the total sample, FE using the representative sample as well as FE models for boys and girls, separately. In each model we control for family background variables.

Finally, we are able to examine how the relationship between early noncognitive skills and our outcome measures change when we estimate FE models for the psychosocial and organic risk sample. Using both subsamples we are able to disentangle both risk factors compared to the total sample, but we risk that our estimates are statistically insignificant due to a smaller sample size.

Our fixed effect results indicate that early noncognitive skills are crucial for the development of noncognitive skills and social outcomes in later life. Infants with low noncognitive skills may experience difficulties in adolescence in terms of educational performance, health behavior patterns, delinquency and autonomy. In particular, the attention span has emerged as dominant factor of noncognitive skills regarding educational performance, health behavior and delinquency in our study. In addition, the child's initial reaction within the first two years of life is associated with most social outcomes. For a child's mood and a child's sensitivity in early childhood we find, except for tobacco use, that only the lowest categories reduce the child's social outcomes, while differences between the middle against the highest category are not significant. We also find that boys with low noncognitive skills in early childhood have significantly lower social outcomes in comparison to girls. These gender differences arise for nearly all outcomes used in the study. 
The paper is organized as follows: In section 2 we describe our selection of noncognitive skills and social outcomes. In section 3 we explain our data set and present descriptive statistics. Section 4 presents the empirical methods. Section 5 analyzes the effects of early noncognitive skills on social outcomes. Section 6 concludes.

\section{Noncognitive skills and social outcomes}

\section{Noncognitive skills}

The temperament is an all-embracing term which constitutes the fundament for the development of personality traits in later life. In the psychological literature individual characteristics shown during childhood and adolescence are variously described as temperament (traits) or as personality traits. In accordance to the economic literature we use the term "noncognitive skills" throughout the paper.

In our data a child's noncognitive skills were assessed in two ways: on the one hand the assessment was based on standardized parent interviews, on the other hand it was based on structured observations in four standardized settings on two different days in both familiar (home) and unfamiliar (laboratory) surroundings. All ratings were made by trained judges on 5-point rating scales adapted from the New York Longitudinal Study NYLS (Thomas et al.; 1968). ${ }^{1}$ We use four dimensions of a child's personality: attention span, approach, prevailing mood and distractibility assessed at the ages of three months and two years.

Attention span refers to the child's ability to concentrate on a particular activity and to continue it in the face of obstacles. The items include aspects on how attentive the child is in different situations, for example the attention to a new plaything, or to a strange person. It also refers to whether or not a child can concentrate on a particular activity for a relatively long time. The attention span is related to task persistence and self-regulation which are both assumed to have

\footnotetext{
${ }^{1}$ At the ages of 3 months and 2 years, the interrater reliability was measured in a preliminary study of 30 children. Satisfactory interrater agreement was obtained between two raters (3 months: mean $\kappa=0.68$, range $0.51-0.84 ; 2$ years: mean $\kappa=0.82$, range $0.52-1.00)$.
} 
a positive impact on the amount of time spent on homework and on a child's participation. In accordance to Thomas et al. (1968) we distinguish between a "low attention span", a "mid attention span" and a "high attention span".

Approach describes how the child reacts to new (strange) people or environments, either in a positive or a negative way. For example, a child who is bold will tend to approach things or persons quickly as if without thinking. In contrast, a child who is cautious typically prefers to watch for a while before opening itself to new experiences. The scale varies between "the child reacts sometimes" versus "the child shows clear interest and smiles".

Prevailing mood refers to the child's general tendency towards good or bad temper. The prevailing mood is an overall assessment of a child's mood in different situations, e.g. a child's mood when he or she goes to sleep or during eating. Infants who smile all the time can be considered as cheerful, while infants who cry all the time can be considered as stormy. Mood lies on a continuum between "bad temper", "satisfaction" and "good temper" in accordance to the classification by Thomas et al. (1968).

Distractibility describes if and how a child is disturbed by changes in his/her environment. Does the child get bothered by external stimuli such as noises or lights or does the child simply ignore them? A child who is difficult to calm will be easily distracted and will not be able to remain concentrated and vice versa. The scale ranges between "difficult to calm", "adequate to calm" and "easy to calm", see Thomas et al. (1968).

\section{Social outcomes in adolescence}

We focus on six different kinds of social outcomes: grades in math and German, delinquency, tobacco and alcohol use and autonomy between 8 and 19 years.

Grades in math and German We use grades in math and German as measures of school performance. Grades in math and German were repeatedly observed at 11 and 15 years. They vary from $1,1.1,1.2, \ldots, 5.9$ to 6 .

Delinquency Adolescents completed a questionnaire which asked individuals at age 15 and 19 what illicit things they had ever done in their life, for example dodging the fare, bunking off or using drugs, even if these things were not known to parents or the police. It is the unproven delinquency, instead of the proven delinquency. In our sample the scale ranges between 0 and 32 criminal activities. 
Smoking Adolescents were asked at age 15 and 19 whether they currently smoke. For our empirical analysis we use a dummy variable which takes the value one if individuals consume tobacco and zero otherwise.

Alcohol consumption Adolescents were administered a substance use questionnaire assessing the average alcohol consumption in the last month at age 15 and 19. The average alcohol use is measured as the number of standard alcohol drinks ${ }^{2}$ such as beer $(0.33 \mathrm{l})$ or a glass wine $(0.125 \mathrm{l})$ or a longdrink/cocktail with $40 \mathrm{ml}$ spirits. The measure varies between 0 and 204 standard drinks per month. ${ }^{3}$

Autonomy This measure is derived from a seven-step five dimensional assessment scale. The goal of this scale is to assess the level of functioning of a child or an adolescent independent from his psychiatric disorder (Marcus et al.; 1993). The five dimensions of the scale include family, performances, peer relationships, interest and autonomy. In our paper we focus on autonomy. It describes the extent of autonomy with regard to age-dependent tasks or problems, for example sleeping alone over night by relatives or defining one's own positions. Autonomy was rated at the ages of 8 and 11 by trained raters based on the Scales for Levels of Functioning (Marcus et al.; 1993). The level of the functioning scales varies between 1 (total dependent)7 (total independent).

\section{Data}

The Mannheim Study of Children at Risk (MARS) ${ }^{4}$ follows children at risk, born with different organic and psychosocial adversities, from birth until adolescence. The initial sample comprises children born in the Rhine-Neckar Region of Germany between February 1986 and February 1988. In order to distinguish between the independent and combined effects of organic and psychosocial risks on child development, the children were selected according to a combination of these two risk factors (see Figure 1).

\footnotetext{
${ }^{2}$ A standard alcohol drink consists of 8-12 g alcohol per drink.

${ }^{3}$ Data concerning the tobacco and alcohol consumption were assessed via the Substance Use Questionnaire designed by Müller and Abbet (1991) in collaboration with the World Health Institute.

${ }^{4}$ MARS is derived from the German title MAnnheimer Risikokinder Studie.
} 
Figure 1: Design of the Mannheim Study of Risk Children

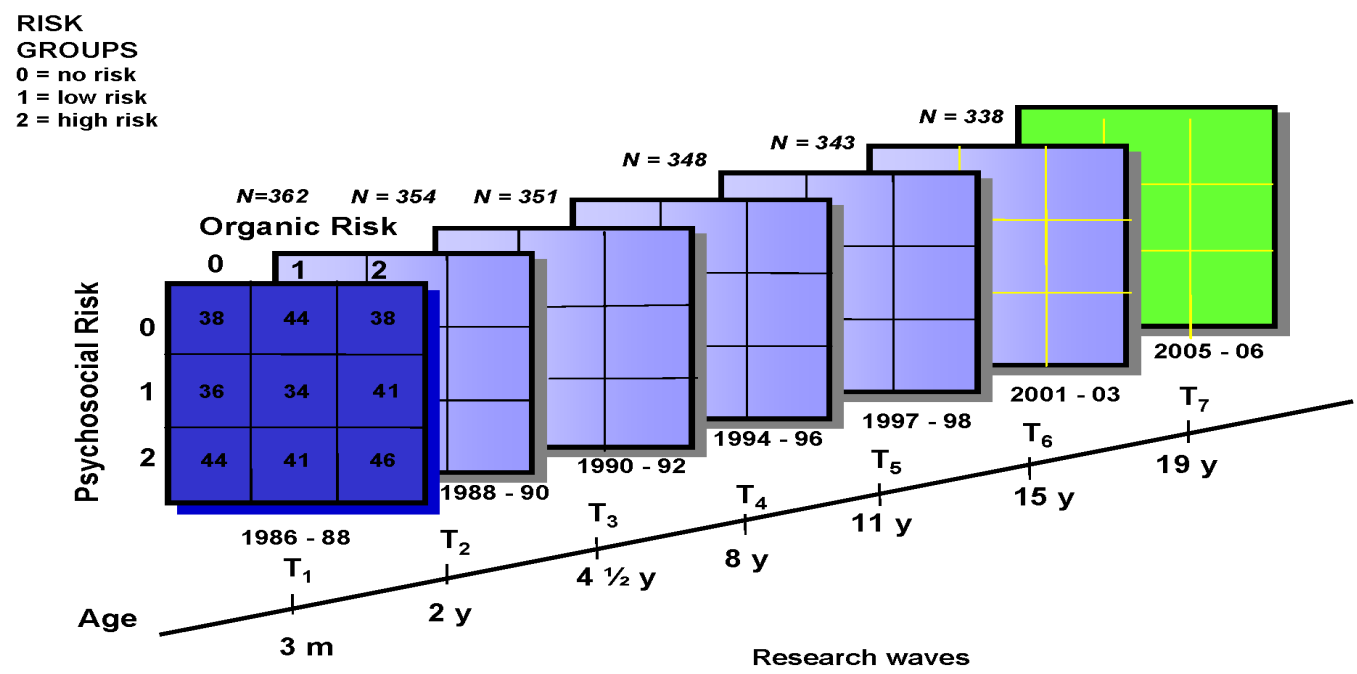

Organic risks are pregnancy or delivery complications, e.g. if a child is born with low birth weight (LBW) or is born preterm, while psychosocial risks are related to the family background, for example a low educational level of the parents, early parenthood or single-parent families. ${ }^{5}$

Both risk factors were divided into "no", "moderate" and "high" risk, respectively. According to this rating, children were assigned to one of the nine groups resulting from the two-factorial design. All groups are of equal size with a slight oversampling in the high-risk combinations and have about the same share of females and males.

To control for confounding effects of the family environment and infant medical status, only firstborn children of German speaking parents took part in the study. Multiple births were not considered, either. Furthermore, children with severe physical handicaps, obvious genetic defects or metabolic diseases at birth were excluded. The participants were primarily of European descent. The initial sample amounts to 384 children. Among them, the first 110 children were randomly selected. 274 children were systematically selected by risk status to ensure that all

\footnotetext{
${ }^{5}$ The psychosocial risk factors are based on the family adversity index proposed by Rutter and Quinton (1977).
} 
of the nine risk combinations are equally distributed. Due to small sample size we constitute a so-called "representative sample" based on these 110 randomly selected children. Each of the 110 individual has a probability (weight) to be in one of the nine resulting groups. Based on the weights we calculate a representative sample.

Medical and psychological examinations of the research waves took place when the children were 3 months, 2, 4.5, 8, 11, 15 and 19 years old and have since then been going on. ${ }^{6}$ For a more detailed overview of the study design, see for instance Laucht et al. (2004), Laucht et al. (2001) or Laucht et al. (1997).

Descriptive statistics: Table 1 presents descriptive statistics of the child's noncognitive skills in early childhood which we used in our study: attention span, approach, prevailing mood and distractibility. ${ }^{7}$ Means and standard deviations for these measures are shown for the total sample, the high risk subsample, the no risk subsample, for girls as well as for boys. The share of children with a low attention span is $10 \%$ in the total sample. In the high risk subsample the share of children with a low attention span is more than twice as large compared to the no risk combination. The proportion of boys with a low attention span is twice as large compared to girls.

Children without risk show a greater interest towards new persons and objects compared to those of the total and high risk subsample. Differences between boys and girls regarding the initial reaction are rather small. In the high risk sample the percentage of children having a bad temper is $34 \%$. The share of boys having a bad temper is ten percent higher compared to girls. Finally, the share of children who tend to be unsensitive to an external stimuli is $6 \%$ higher in the high risk sample compared to the no risk samples. In line with other dimension of a child's temperament, boys have lower noncognitive skills compared to girls, at least regarding early childhood.

The stability of the temperament in early childhood is rather weak. Correlation

\footnotetext{
${ }^{6}$ Participants with severe handicaps, IQ $<70, \mathrm{MQ}<70$ or neurological disorder were excluded from the original sample.

${ }^{7}$ We calculated joint means and standard deviations for both ages, three months and two years.
} 
analyses of all four noncognitive skills between three months and two years show only weak associations which is in line with the psychological literature (Nigg; 2006). The highest (lowest) correlation is 0.17 (0.01) for distractibility (for prevailing $\operatorname{mood}) .^{8}$

Table 2 reports educational outcomes, delinquency, tobacco and alcohol consumption and autonomy of the adolescents. In accordance with the summary statistics of the early noncognitive skills, we regard these outcomes for all five samples. Depending on the social outcome, we repeatedly observe this information when individuals are between 8-19 years old.

Differences between the high risk and the no risk sample are quite large for most of the outcomes. For all samples, educational performance is on average higher for grades in German than for grades in math, where higher means imply worse achievements. Grades in maths are better for boys, while grades in German are better for girls.

The number of criminal activities is on average twice as large among adolescents in the high risk sample compared to the no risk sample. The result indicates that individuals growing up with less educated parents or even with delinquent parents are more likely to become delinquent themselves. Boys are on average nearly more than twice as often criminal than girls.

For the health risk behavior in terms of tobacco and alcohol use, we find that adolescents who were born with two risk factors have a worse health behavior compared to children born with no risk. The average alcohol consumption in terms of average standard alcohol drinks is more than twice as large among boys in comparison to girls. Finally, autonomy seems to be higher for girls compared to boys in our data.

\footnotetext{
${ }^{8}$ However, agreement exists to consider temperament as something which develops very early and as biologically rooted differences in behavioral tendencies that are relative stable during lifetime (Pitzer et al.; 2007).
} 


\section{Empirical Methods}

This section will discuss our framework for identifying the long term effects of early noncognitive skills. Let

$$
Y_{i t}=\alpha+\beta N C_{i s}+X_{j i t}^{\prime} \lambda+f_{i}+u_{i t}
$$

where $Y_{i t}$ denotes the social outcomes (school achievement, health behavior, delinquency and autonomy) of individual i in t (during the age between 8 and 19 years), $N C_{i s}$ represents the child's i early noncognitive skills in s (at the age of 3 months and 2 years), $X_{j i t}$ is a vector of parental characteristics $\mathrm{j}$ at t, including a dummy variable indicating whether the adolescent lives in a single parent household, a set of dummies for the family size and family changes until adolescence of the child i. All variables captured in $X_{j i t}$ refer to the period when children are between 8 and 19 years old. Given the study design we do not have to control for the birth order due to the fact that only the firstborn child and only singleton births were considered in the study. As mentioned above, we do not have to take into account birth cohort effects or regional effects since all individuals were born between 1986 and 1988 in the Rhine-Neckar Region. $u_{i t}$ is the individual specific idiosyncratic error term, assumed to be independent of all observable and unobservable factors.

Finally, $f_{i}$ describes the unobserved individual effect. This effect can cover features of an individual such as genetic endowment or parental motivation towards the upbringing of their child that are given and do not change over time. Contrary to initial theories of temperament, new findings show that heritability plays a substantial role in the development of major traits during early childhood. For example, dopamine genes may influence to some extent temperament, but may also be related to a range of other abilities and functions e.g. cognitive abilities, learning abilities or motor control (Nigg; 2006).

Our central parameter of interest is $\beta$ and its magnitude is relevant for policy implications. If $\beta$ has large and positive impacts on social outcomes, one might expect substantial benefits from interventions that improve early noncognitive skills. A cross-sectional estimation of equation (1) without considering $f_{i}$ will lead to biased estimates of $\beta$, because unobserved time-invariant and individual specific elements of $f_{i}$ might influence both early noncognitive skills and outcomes 
in adolescence. Thus, even if there is a strong correlation between social outcomes and early noncognitive skills, the strength of the correlation could be driven by the correlation between early noncognitive skills and unobservable genetic factors captured in $f_{i}$.

Identification strategy: We observe social outcomes in adolescence at two different ages (from 8 to 19 years). Noncognitive skills in early childhood are also observed at two different ages (at 3 months and at 2 years). We exploit cross-variation in individual-specific one-period changes in regressors and individual specific one period changes in the dependent variables to identify $\beta$. Lagging equation (1) by one period yields:

$$
Y_{i t-1}=\alpha+\beta N C_{i s-1}+X_{j i t-1}^{\prime} \lambda+f_{i}+u_{i t-1}
$$

Subtracting (2) from $Y_{i t}(1)$ yields the first-differences model:

$$
\left(Y_{i t}-Y_{i t-1}\right)=\beta\left(N C_{i s}-N C_{i s-1}\right)+\left(X_{j i t}-X_{j i t-1}\right)^{\prime} \lambda+\left(u_{i t}-u_{i t-1}\right)
$$

Under the assumption that $u_{i t}$ is uncorrelated with $N C_{i s}$, the fixed effects estimator $\beta_{F E}$ is unbiased for $\beta .^{9} \Delta N C_{i s}$ denotes the change between noncognitive skills at three months and two years. At the age of three months these skills can be regarded as the result of genetic endowment, while noncognitive skills at the age of two years are the result of early parent-child interactions. The difference in noncognitive skills can therefore be regarded as parental investment in noncognitive skills.

We estimate different fixed effect models on the child level for each outcome. ${ }^{10}$ Models for grades in math and German:

$$
\left(Y_{i 15}-Y_{i 11}\right)=\beta\left(N C_{i s}-N C_{i s-1}\right)+\left(X_{j i 15}-X_{j i 11}\right)^{\prime} \lambda+\left(u_{i 15}-u_{i 11}\right)
$$

In equation (4) we are interested in how an increase in early noncognitive skills leads to an increase in school performance during the age between 11 and 15 years. Models for delinquency, smoking and alcohol consumption refer to later points in

\footnotetext{
${ }^{9}$ Since we observe each social outcome only for two different ages the first-differences estimator is equivalent to the within estimator.

${ }^{10}$ This is due to the fact that social outcomes differ in duration and age, when they are assessed for the first time.
} 
time:

$$
\left(Y_{i 19}-Y_{i 15}\right)=\beta\left(N C_{i s}-N C_{i s-1}\right)+\left(X_{j i 19}-X_{j i 15}\right)^{\prime} \lambda+\left(u_{i 19}-u_{i 15}\right)
$$

Parental investment reduces health risk behavior and reduces criminal activities and therefore we would expect that $\beta$ is negative.

Model for autonomy:

$$
\left(Y_{i 11}-Y_{i 8}\right)=\beta\left(N C_{i s}-N C_{i s-1}\right)+\left(X_{j i 11}-X_{j i 8}\right)^{\prime} \lambda+\left(u_{i 11}-u_{i 8}\right)
$$

In equation (6) we are interested in how an increase in early noncognitive skills leads to an increase in a child's autonomy during the age between 8 and 11 years.

For each skill we compute categories (dummy variables) to estimate possible nonlinear effects of early noncognitive skills. For example, differences in health behavior or school attainment may appear only for the fraction with a low attention span. In this case, a linear regression would not adequately capture this relationship.

As for the attention span, we estimate noncognitive skill effects in early childhood by comparing a "low" attention or a "mid" attention to a "high" attention span (baseline category). For the approach, we distinguish between two groups: whether the child reacts sometimes to a strange (new) person and whether the child shows a "high interest" toward a strange person (reference group). As for the third noncognitive skill, we compare "bad" temper and "satisfied" with "good" temper (baseline category). Regarding the fourth skill in early childhood, we compare "difficult" to calm and "adequate" to calm to the reference category "easy" to calm. ${ }^{11}$

For each noncognitive skill in early childhood, we estimate five different models: OLS using the total sample ${ }^{12}$; FE using the total sample; FE using the representative sample; and FE models for girls and boys, separately.

\footnotetext{
${ }^{11}$ We re-estimate all models using linear specifications. The results are similar. They are available from the authors upon request.

${ }^{12}$ This estimation strategy allows us to compare the OLS coefficient in the total sample to the FE coefficient in the total sample.
} 


\section{Results}

Table 3 shows the effects of early noncognitive skills on grades in math. Column 1 displays the OLS coefficients of all noncognitive skills for the total sample. The second column reports the FE results for the same sample. Columns 3-5 present FE results for the weighted (representative) sample, for boys and for girls. All models include a dummy variable which indicates whether a child lives in a single household, a dummy variable for the number of household members (from two to more than 5 members) and a dummy variable which takes the value one if the family composition has not changed until now. All subsequent tables present estimation results for other outcomes but have the same structure. ${ }^{13}$

The results in Table 3 show that children with a low or mid attention span have significantly lower grades in math than those with a high attention span. This relationship holds in all models. The estimated coefficient between the total sample and the representative sample remains virtually unchanged. The relatively higher association between the attention span and grades in math is smaller for those with a mid attention span. A low attention span might indicate attention problems in early childhood, which is one symptom of ADHD (Nigg et al.; 2004). ADHD symptoms lead to lower reading and math test scores (Currie and Stabile; 2006). Nigg et al. (2004) find that early attention problems remain fairly stable over time, which might reduce learning opportunities. Finally, boys with a low attention span have lower school achievements compared to girls.

The second part of Table 3 presents the same results but uses approach instead of attention categories. Children who "react sometimes" have on average 0.23 lower grades in math than those with a "high interest".

The fact whether a child had a bad temper, was satisfied or was in a good temper in early childhood seems to have no impact on grades in maths.

The last results in Table 3 indicate that children who were difficult to calm within the second year of life have significantly poorer grades in math. Interestingly, $\beta$

\footnotetext{
${ }^{13}$ Disabled persons are observed until age 11. Thus, for school grades and autonomy, we have observed their outcomes, however, for reasons of comparison we exclude all disabled persons from our analysis (3 observations).
} 
is quite equal in the total (risk) sample and in the total (representative) sample. Moreover, these results show that only children who were difficult to calm perform more poorly in school in later life, while the association is insignificant for the category "adequate to calm". ${ }^{14}$

Table 4 displays the estimation results for the influence of all early noncognitive skills on grades in German between the age of 11 and 15 years. In accordance to the results presented before, a low attention span in early childhood ceteris paribus causes lower school performance in terms of grades in German. The effect is stronger for the lowest attention category in comparison to children having at least a mid attention span. In comparison to grades in math, the attention span seems to be less important for explaining differences regarding grades in German. Both, the results for grades in math and in German, are in line with previous studies which found links between attention abilities and later achievement. For example the study of Duncan et al. (2007) shows that the attention span is an important predictor for school reading and math achievements. Further, while a low attention span for boys is associated with worse grades in German, a low attention span for girls does not matter for grades in German (see Table 9). This result is in line with a most recent study by Freudenthaler et al. (2008).

Children who showed a high interest at the beginning of life towards a strange person have significantly better grades in German than children who reacted only sometimes to a new person or a new object.

For a child's mood in early childhood, columns 1, 2 and 4 suggest an influence between early noncognitive skills and grades in German. However, these associations cannot be observed in the representative sample and they cannot be observed for girls. In line with the results before, only the extremely low mood category leads to adverse impacts on grades in German, except for boys.

Surprisingly, if we estimate models 1-5 in Table 4 using grades in German instead of grades in math, only the OLS model shows a significant association between

\footnotetext{
${ }^{14}$ For all models presented in Table 3 OLS estimate are rather similar to FE estimates.
} 
early noncognitive skills and grades in German. A significant relationship between early noncognitive skills and school outcomes in our sample neither exists for the total sample (column 2) nor for the total representative sample (column 3). This suggests that different school outcomes require different aspects of early noncognitive skills. Altogether, comparing grades in math with grades in German, noncognitive skills seems to be more important for grades in math, while they seem to be less important for grades in German. ${ }^{15}$

Criminal activities during adolescents can be the result of various possible behavioral aspects, one is the early temperament (Loeber; 1990). Table 5 shows that the attention span during early childhood is a very important noncognitive skill for explaining the differences in delinquency of the 15-19 years old: On average, children with a low attention span and children with a mid attention span during early childhood will become more often delinquent in comparison to children with a high attention span, accounting for family background variables. Previous research has reported that ADHD is a risk factor for later delinquency in adolescence (Herrenkohl et al.; 2000). This finding holds for all models presented in the top of Table 5, except for girls. Children who had a low attention span between the age of 3 months and 2 years commit on average 3.24 more criminal activities than children of the high attention group. The significant association holds also for the category "mid" attention span, but the extent is smaller compared to children with a low attention span. Boys who had a low and mid attention span during early childhood behave more delinquent than girls. Some studies have shown that gender is itself a risk factor for delinquent behavior (Pardini et al.; 2006).

Table 5 provides estimates of how the dimension "approach" in early childhood impacts delinquent behavior in juveniles. Children who had a poor initial reaction in early childhood are more often criminal than children who were more interested to strange objects and persons. Boys who react only sometimes commit on average 2.30 criminal activities, while for girls we find no significant influence.

\footnotetext{
${ }^{15}$ We reexamined our main estimation for grades in math and German taking into account that a good grade at the highest school track indicates a higher school performance than a good grade at the lowest school track. Yet, for the (total) risk sample, the results are much stronger for the lowest skill category and become often insignificant for the mid against the highest skill category. The results are not reported here, but available from the authors upon request.
} 
The fact whether a child was in a good or bad temper in his first years of life seems to have no consequences with regard to delinquency in adolescence. This is true for all models presented in Table 5. Simple $C h i^{2}$-tests also do not indicate any significant influence of early noncognitive skills on later delinquency. The child's mood in early childhood is rather instable over time, which might explain why there is no association between early mood and delinquency in adolescence.

Finally, the facts are similar when we turn to distractibility. For some models we find that children who were difficult to calm during early childhood commit on average 1.61 more criminal activities in adolescence than children who were easy to calm. However, these effects are only significant at the $10 \%$ level. The impact is more than twice as large for boys. The tendency to withdraw from unknown and dangerous situations is considered to be one aspect of a difficult child temperament, however, this will increase conduct problems (Frick and Morris; 2004).

Table 6 and Table 7 present the relationship between early noncognitive skills and a risky health behavior in adolescence. Several studies suggest that the strong link between the use of tobacco and alcohol could be partly explained by personality traits for example, Cloninger et al. (1988) and Conway et al. (2002). Table 6 shows the estimated effects of early noncognitive skills on the probability of smoking between the age of 15 and 19 years.

Except for girls (column 5) all FE and OLS results indicate a substantial relationship between attention problems in early childhood and the probability of smoking in adolescence. Adolescents have a 13 percentage point higher probability of smoking if they had only a low attention span in their first years of life. The marginal probability of smoking is twice as high for boys at the age of 15 and 19 years compared to the representative sample.

The effects of "approach" at the ages of three months and two years on smoking in adolescence are significant in the OLS specification, stronger in the FE specification in the full risk sample as well as in the representative sample, but insignificant for girls. The FE results in column 2 and 3 indicate a significant relationship between early noncognitive skills and smoking in adolescence. The estimated effect is equal 
in both samples.

A young adult who often had a bad temper in early childhood has a $16 \%$ higher probability (representative sample) of smoking than his or her counterpart with a good temper during early childhood. Interestingly, the probability of smoking is even $26 \%$ higher for young girls with a bad temper in early childhood. No model presented in Table 6 shows significant differences between satisfied children and children with a good temper in terms of smoking in adolescence.

The distractibility results within the FE context show no significant differences in all models between those children who were difficult to calm and those children who were easy to calm in early childhood. In contrast, children who were adequate to calm have a significantly lower probability of smoking at the age of 15-19 years in the total risk sample, in the representative sample and for girls compared to children who were easy to calm.

The results in Table 7 indicate that early noncognitive skills are also associated with a risky health behavior in terms of alcohol consumption between 15 and 19 years. Children who had a low attention span or a mid attention span in early childhood consume significantly more alcohol on average compared to those with a high attention span. For example, the average number of alcoholic drinks is 22.77 times higher per months in the group of children having a low attention span compared to children who had a high attention span in early childhood. For children who had a middle attention span, it is 11.30 times higher per months compared to children who had a high attention span. Gender differences are quite large. Boys with a low attention span consume on average four times more alcoholic drinks than girls with a low attentions span.

The average alcohol consumption is higher for children who had low noncognitive skills in early childhood in terms of "approach". For all samples we find that children who reacted only sometimes to new (strange) persons in early childhood drink significantly more alcohol in adolescence than their counterparts.

In our data, mood in early childhood does not matter for the average monthly alcohol consumption in adolescence. We find neither a significant difference 
between children who had a bad temper during early childhood compared to satisfied children nor between satisfied children and children with a good temper in any model specification.

While a child's distractibility has no lasting impact on the smoking behavior as adolescent, it has substantial effects on the average monthly alcohol consumption as adolescent. Differences are only quite large between the two extreme categories "difficult to calm" and "easy to calm", while differences between "adequate to calm" and "easy to calm" are not significant. Bobo and Husten (2000) found that the majority of tobacco smokers also consumed alcohol, whereas only half of the current alcohol users also smoked. Their investigation showed that the concurrent user group could be distinguished from the users of alcohol by higher novelty seeking scores. Finally, the positive relationship between high noncognitive skills and healthier behavior is most pronounced for boys.

We find that for most noncognitive skills, boys with the same stock of noncognitive skills (attention span, approach, distractibility) have a significantly higher alcohol consumption than girls. The risk-taking tendency may be more common among males than among females (Haas; 2004).

We conclude our analysis by considering how early noncognitive skills influence autonomy. The results in Table 8 indicate that in contrast to the substantial effect of the early attention span on later school performance, health risk behavior and delinquency, there is no impact on a child's autonomy at the age between 8 and 11 years. This holds for each category relative to the baseline category and for all FE model specifications. Further, the null hypothesis of no impact of early noncognitive skills on a child's autonomy cannot be rejected.

In contrast to the attention span the dimension "approach" in early childhood contributes to the development of autonomy. For the development of autonomy the initial reaction to (strange) persons in early childhood matters. Our results are in contrast with our prior expectations that infants who reacted only in some cases to strange persons and objects might be considered as less open and withdrawn which in turn later manifests itself in low autonomy at the age between 8 and 11 years. 
Children who had a bad temper during early childhood are significantly less independent when they are older compared to children who were at least satisfied. The result holds for all models, except for boys (column 4). The association between mood in early childhood and autonomy between the age of 8 and 11 years is most pronounced among girls. An infant's distractibility does not contribute to the development of autonomy between the age of 8-11 years, except for girls. Girls who are easy to calm become more independent as adolescents compared to boys.

Robustness: Our results are subject to one major limitation regarding the representatives due to the oversampling of risk children. However, one advantage of the study design is we can examine which of the risk factors (psychosocial and organic) has more detrimental effects in terms of outcomes in adolescence. Using both subsamples we are able to disentangle both risk factors compared to the total sample, but we risk that our estimates are statistically insignificant due to a smaller sample size. In Table 9- Table 11 we split the total (risk) sample into the psychosocial and organic risk sample, which means that individuals with an organic risk are excluded from the former and individuals with psychosocial risk are excluded from the latter subsample. In both samples we exclude individuals with no risks.

In the following we restrict the interpretation of the findings of main differences between the samples. First, after separating the full sample, the estimated coefficient in the psychosocial (organic) risk sample falls (rises) from 0.57 to 0.48 (1.07). ${ }^{16}$ Children born with a low attention span and born with pre- or neonatal complications face worse grades in math and German than children with a low attention span and no organic risk. This result supports earlier findings on the effects of poor infant health on school achievements (for example Currie and Hyerson (1999), Black et al. (2005) and Oreopoulos et al. (2008)).

In contrast, using the psychosocial and organic subsample, however, we find no significant relationship between noncognitive skills in terms of approach, prevailing mood and distractibility and grades in math and German up to age of 15 at least

\footnotetext{
${ }^{16}$ Note that the coefficients are measured less precisely to a smaller sample size.
} 
Figure 2: Risk subsamples

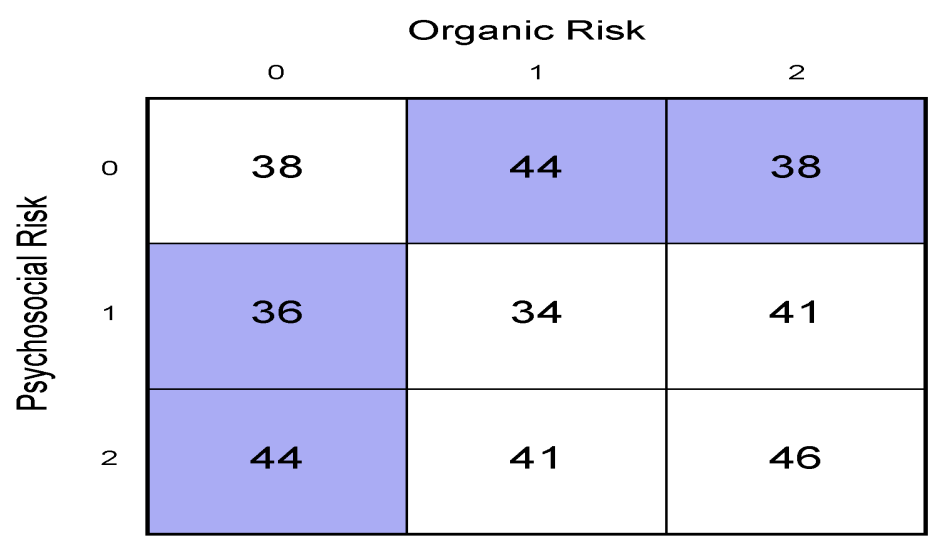

at the five percent level.

The results in Table 10 indicate that the relationship between noncognitive skills in early childhood and health risk behavior (tobacco and alcohol consumption) in adolescence is more pronounced among children born with psychosocial risk. This suggests that psychosocial risks and low noncognitive skills at birth amplify the adverse impact of the probability of tobacco and alcohol use. The impact of the quality of family environment on later tobacco and alcohol consumption is cumulative (Anda et al.; 1999).

Finally, we find a slightly higher risk of becoming delinquent in the psychosocial subsample compared to the organic risk subsample. 


\section{Outlook and Concluding Remarks}

The paper contributes to the recent discussion on the relevance of early noncognitive skills for human capital accumulation. We use a longitudinal epidemiological cohort study of 384 children at risk from the Rhine-Neckar Region in Germany to examine the medium term consequences of noncognitive skills. Using four different measures of a child's noncognitive skills, attention span, approach, prevailing mood and distractibility assessed at the age of three months and two years, we find that noncognitive skills are significantly associated with most social outcomes observed by the study. These results hold for the full (risk) sample, the representative sample as well as for the organic and psychosocial risk sample. Most noncognitive skills in early childhood are important predictors of educational performance, health risk behavior, delinquency and autonomy in adolescence.

The attention span has emerged as a dominant factor of noncognitive skills regarding educational performance, health risk behavior and delinquency in our study. Moreover, the child's initial reaction within the first two years of life is also associated with most social outcomes in adolescence. The child's attention span and the child's approach appear to be stronger predictors than a child's mood and a child's distractibility in the models for health risk behavior and juvenile delinquency. For a child's mood and a child's distractibility in early childhood we find, except for tobacco use, that only the extreme low categories reduce the child's social outcomes in adolescence, while differences between the middle against the highest category are not significant.

Further, gender differences can be observed for nearly all outcomes used in the study. Boys with low noncognitive skills in early childhood have significantly lower social outcomes in comparison to girls in adolescence. Finally, we find for most social outcomes that low noncognitive skills in either the organic or psychosocial risk group have additionally adverse effects. In particular, for children born with organic risk, the association between low noncognitive skills in early childhood and poor school achievements during adolescence is stronger compared to children born with psychosocial risks. In contrast, for children born with psychosocial risks, the association between low noncognitive skills in early childhood and alcohol consumption as adolescent is higher compared to children born in the other risk group. 
Our evidence supports the importance of noncognitive skills in early childhood as a predictor of a variety of social outcomes in adolescence. The enhancement children's noncognitive skills will affect later skills which in turn affect a variety of economic and noneconomic outcomes (Cunha et al.; 2006). This confirms earlier findings that much of the effectiveness of early childhood interventions comes from the promotion of noncognitive skills, such as self-esteem, learning abilities, peer interaction and the ability to overcome shyness (Currie and Blau; 2005).

Although noncognitive skills are malleable until the early 20s (Dahl; 2006), interventions in a period of relatively high malleability are more likely to succeed than interventions in a period of reduced malleability. Therefore, economic and noneconomic returns of early investments are higher. 


\section{References}

Anda, R. F., Croft, J. B., Felitti, V. J., Nordenberg, D., Giles, W. H., Williamson, D. F. and Giovino, G. A. (1999). Adverse childhood experiences and smoking during adolescence and adulthood, Journal of American Medical Association 282: 1652-1658.

Black, S. E., Devereux, P. J. and Salvanes, K. (2005). Why the apple doesn't fall far: Understanding the intergenerational transmission of Human Capital, American Economic Review 95 (1): 437-449.

Bobo, J. K. and Husten, C. (2000). Sociocultural influences on smoking and drinking, Alcohol Research and Health 24: 201-208.

Borghans, L., Duckworth, A. L., Heckman, J. J. and ter Weel, B. (2008). The Economics and Psychology of Personality Traits, Journal of Human Resources 43 (4).

Bowles, S., Gintis, H. and Osborne, M. (2001). The Determinants of Earnings: A Behavioral Approach, Journal of Economic Literature 39 (4): 1137-1176.

Carneiro, P., Crawford, C. and Goodman, A. (2008). The Impact of Early Cognitive and Non-Cognitive skills on Later Outcomes, Working Paper.

Claessens, A., Duncan, G. J. and Engel, M. (2006). Kindergarten Skills and Fifth Grade Achievement: Evidence from the ECLS-K, Discussion Paper Northwestern University .

Cloninger, C. R., Sigvardsson, S. and Bohmann, M. (1988). Childhood personality predicts alcohol abuse in young adults, Alcoholism, Clinical and Experimental Research 12: 494-505.

Conway, K. P., Swendsen, J. D. and Rounsaville, B. J. (2002). Personality, drug of choice, and comorbid psychopathology among substance abusers, Drug and Alcohol Dependence 65: 225-234.

Cunha, F., Heckman, J. J., Lochner, L. and Masterov, D. V. (2006). Interpreting the Evidence on Life Cycle Skill Formation, in F. Welch and E. Hanushek, eds., The Handbook of the Economics of Education, Amsterdam: North-Holland. 
Currie, J. and Blau, D. (2005). Who's Minding the Kids?: Preschool, Day Care, and After School Care, in F. Welch and E. Hanushek, eds., The Handbook of the Economics of Education, Amsterdam: North-Holland.

Currie, J. and Hyerson, R. (1999). Is the Impact of Health Shocks Cushioned by Socioeconomic Status? The Case of Low Birth Weight, American Economic Review 89: 245-250.

Currie, J. and Stabile, M. (2006). Child Mental Health and Human Capital Accumulation: The Case of ADHD, Journal of Health Economics 25 (6): 1094-1118.

Dahl, R. E. (2006). Adolescent Brain Development: A Period of Vulnerabilities and Opportunities, in Annuals of the New York Academy of Science, ed. by R. E. Dahl and L. P. Spear, New York: New York Academy of Science.

Deal, J. E., Halverson, C. F., Havill, V. and Martin, R. P. (2005). Temperament Factors as Longitudinal Predictors of Young Adult Personality, Journal of Developmental Psychology 51.

Duckworth, A. L. and Seligman, M. E. P. (2005). Self-Discipline Outdoes IQ in Predicting Academic Performance in Adolescents, American Psychological Society 16: $939-944$.

Duncan, G., Claessens, A. and Engel, M. (2001). The Contributions of Hard Skills and Socio-Emotional Behavior to School Readiness, Working Paper, Northwestern University .

Duncan, G. J., Claessens, A., Huston, A. C., Pagani, L. S., Engel, M., Sexton, H., Dowsett, C. J., Magnuson, K., Klebanov, P., Feinstein, L., Brooks-Gunn, J. and Duckworth, K. (2007). School Readiness and Later Achievement, Developmental Psychology 43 (6): 1428-1446.

Freudenthaler, H. H., Spinath, B. and Neubauer, A. C. (2008). Predicting school achievement in boys and girls, European Journal of Personality 22 (3): 231-245.

Frick, P. J. and Morris, A. S. (2004). Temperament and Developmental Pathways to Conduct Problems, Journal of Clinical Child and Adolescent Psychology 33 (1): $54-68$.

Gordon, N. (1993). Learning disorder and delinquency, Brain \& Development 15: $169-172$. 
Haas, K. (2004). Relationship of Gender to Licit and Illicit Drug Use among Adolescents, Annual Review of Undergraduate Research at the College of Charleston 3: $92-100$.

Heckman, J. J., Stixrud, J. and Urzua, S. (2006). The Effects of Cognitive and Noncognitive Abilities on Labor Market Outcomes and Social Behavior, Journal of Labor Economics 24 (3): 411-482.

Herrenkohl, T., Maguin, E., Hill, K. G., Hawkins, J. D., Abbott, R. D. and Catalano, R. F. (2000). Developmental Risk Factors for Youth Violence, Journal of Adolescent Health 26: 176-186.

Kagan, J. and Snideman, N. (1999). Early childhood predictors of adult anxiety disorder, Biological Psychiatry 46: 1536-1541.

Kagan, J. and Snideman, N. (2004). The long shadow of temperament, Cambridge, MA: Harvard University .

Laucht, M., Esser, G. and Schmidt, M. H. (1997). Developmental outcome of infants born with biological and psychosocial risks, Journal of Child Psychology and Psychiatry 38 (7): 843-854.

Laucht, M., Esser, G. and Schmidt, M. H. (2001). Differential development of infants at risk for psychopathology: The moderating role of early maternal responsivity, Developmental Medicine and Child Neurology 43 (5): 292-300.

Laucht, M., Esser, G. and Schmidt, M. H. (2004). The development of at-risk children in early life, Educational and Child Psychology 21 (1): 20-31.

Loeber, R. (1990). Development and Risk Factors of Juvenile Antisocial Behavior and Delinquency, Clinical Psychology Review 10: 1-40.

Marcus, A., Blanz, B., Esser, G., Niemeyer, J. and Schmidt, M. H. (1993). Beurteilung des Funktionsniveaus bei Kindern und Jugendlichen mit psychischen Störungen, Kindheit und Entwicklung pp. 166-172.

Martin, R., Olejnik, S. and Gaddies, L. (1994). Is temperament an important contributor to schooling outcomes in elementary school? Modeling effects of temperament and scholastic ability on academic achievement., in: W.B. Carey and S.C. McDevitt (Ed.) Prevention and early intervention. Individual differences as risk factors for the mental health of children. A Festschrift for S. Chess and A. Thomas. 
Müller, R. and Abbet, J. P. (1991). Changing Trends in the Consumption of Legal and Illegal Drugs by 11-16-year old Adolescent Pupils. Findings from a Study Conducted under the Auspics of the WHO Europe., Swiss Professional Service for Alcohol Problems, Lausanne .

Nigg, J. T. (2006). Temperament and developmental psychopatholgy, Journal of Child Psychology and Psychiatry 47 (3/4): 395-422.

Nigg, J. T., Goldsmith, H. H. and Sachek, J. (2004). Temperament and Attention Deficit Hyperactivity Disorder: The Development of a Multiple Pathway Model, Journal of Clinical Child and Adolescent Psychology 33 (1): 42-53.

Oreopoulos, P., Stable, M., Walld, R. and Roos, L. L. (2008). Short-, Medium-, and Long-Term Consequences of Poor Infant Health: An Analysis Using Siblings and Twins, Journal of Human Resources 43 (1).

Pardini, D., Obradovic, J. and Loeber, R. (2006). Interpersonal callousness, hyperactivity/impulsivity, inattention, and conduct problems as precursors to delinquency persistence in boys: a comparison of three grade-based cohorts, Journal of Clinical Child and Adolescent Psychology 35: 46-59.

Pitzer, M., Esser, G., Schmidt, M. H. and Laucht, M. (2007). Temperament in the developmental course: a longitudinal comparison of New York Longitudinal Study- derived dimensions with the Junior Temperament and Character Inventory, Comprehensive Psychiatry 48: 572-582.

Rutter, M. and Quinton, D. (1977). Psychiatric disorder - ecological factors and concepts of causation., in: M. McGurk, editor Ecological factors in human development, Amsterdam: North Holland.

Shiner, R. L. and Caspi, A. (2003). Personality differences in childhood and adolescence: measurement, development, and consequences., Journal of Child Psychology and Psychiatry 44 (1): 2-32.

Shiner, R. L., Masten, A. S. and Roberts, J. M. (2003). Childhood Personality Foreshadows Adult Personality and Life Outcomes Two Decades Later, Journal of Personality 71 (6): 1145-1170.

Shirley, Y. H., Shen, S., Lowers, L. and Locke, J. (2000). Factors Predicting the Onset of Adolescent Drinking in Families at High Risk for Developing Alcoholism, Biological Psychiatry 48: 265-275. 
Thomas, A., Chess, S. and Birch, H. G. (1968). Temperament and behavior disorders in children, New York: University Press. 


\section{A Appendix}

Table 1: Descriptive statistics of early noncognitive skills (3 months-2 years)

\begin{tabular}{|c|c|c|c|c|c|}
\hline & Mean & std.dev. & Mean & std.dev. & $\mathrm{N}$ \\
\hline Attention span & \multicolumn{2}{|c|}{ Low attention span } & \multicolumn{2}{|c|}{ Mid attention span } & \\
\hline Total sample & 0.10 & 0.30 & 0.27 & 0.44 & 353 \\
\hline High risk subsample & 0.14 & 0.35 & 0.36 & 0.48 & 33 \\
\hline No risk subsample & 0.06 & 0.23 & 0.24 & 0.43 & 44 \\
\hline Boys & 0.14 & 0.34 & 0.29 & 0.45 & 169 \\
\hline Girls & 0.07 & 0.26 & 0.25 & 0.44 & 184 \\
\hline Approach & \multicolumn{2}{|c|}{ React sometimes } & & & \\
\hline Total sample & 0.43 & 0.49 & & & 353 \\
\hline High risk subsample & 0.49 & 0.50 & & & 33 \\
\hline No risk subsample & 0.28 & 0.45 & & & 44 \\
\hline Boys & 0.45 & 0.50 & & & 169 \\
\hline Girls & 0.40 & 0.49 & & & 184 \\
\hline Prevailing Mood & \multicolumn{2}{|c|}{ Bad temper } & \multicolumn{2}{|c|}{ Satisfied } & \\
\hline Total sample & 0.29 & 0.45 & 0.57 & 0.49 & 353 \\
\hline High risk subsample & 0.34 & 0.48 & 0.48 & 0.50 & 33 \\
\hline No risk subsample & 0.23 & 0.43 & 0.58 & 0.50 & 44 \\
\hline Boys & 0.34 & 0.47 & 0.53 & 0.50 & 169 \\
\hline Girls & 0.24 & 0.43 & 0.61 & 0.49 & 184 \\
\hline Distractibility & \multicolumn{2}{|c|}{ Difficult to calm } & \multicolumn{2}{|c|}{ Adequate to calm } & \\
\hline Total sample & 0.21 & 0.41 & 0.54 & 0.50 & 353 \\
\hline High risk subsample & 0.24 & 0.43 & 0.50 & 0.50 & 33 \\
\hline No risk subsample & 0.18 & 0.39 & 0.49 & 0.50 & 44 \\
\hline Boys & 0.27 & 0.44 & 0.52 & 0.50 & 169 \\
\hline Girls & 0.16 & 0.36 & 0.56 & 0.50 & 184 \\
\hline
\end{tabular}

The psychosocial (organic) risk sample excludes individuals with organic (psychosocial) risk. 
Table 2: Descriptive statistics of social outcomes in adolescence

\begin{tabular}{|c|c|c|c|c|}
\hline & Mean & std.dev. & $\begin{array}{l}\text { Age of indi- } \\
\text { vidual }\end{array}$ & $\mathrm{N}$ \\
\hline \multicolumn{5}{|c|}{ Grade Math } \\
\hline Total sample & 2.73 & 1.01 & $11-15$ & 353 \\
\hline High risk subsample & 3.01 & 0.93 & $11-15$ & 33 \\
\hline No risk subsample & 2.42 & 0.95 & $11-15$ & 44 \\
\hline Boys & 2.67 & 1.01 & $11-15$ & 169 \\
\hline Girls & 2.78 & 1.0 & $11-15$ & 184 \\
\hline \multicolumn{5}{|c|}{ Grade German } \\
\hline Total sample & 2.66 & 0.91 & $11-15$ & 353 \\
\hline High risk subsample & 2.90 & 0.85 & $11-15$ & 33 \\
\hline No risk subsample & 2.38 & 0.81 & $11-15$ & 44 \\
\hline Boys & 2.82 & 0.91 & $11-15$ & 169 \\
\hline Girls & 2.52 & 0.88 & $11-15$ & 184 \\
\hline \multicolumn{5}{|c|}{ Delinquency } \\
\hline Total sample & 5.34 & 5.62 & $15-19$ & 337 \\
\hline High risk subsample & 6.93 & 6.52 & $15-19$ & 32 \\
\hline No risk subsample & 3.61 & 4.89 & $15-19$ & 42 \\
\hline Boys & 6.91 & 6.57 & $15-19$ & 160 \\
\hline Girls & 3.95 & 4.16 & $15-19$ & 177 \\
\hline \multicolumn{5}{|c|}{ Smoking } \\
\hline Total sample & 0.36 & 0.48 & $15-19$ & 337 \\
\hline High risk subsample & 0.41 & 0.50 & $15-19$ & 32 \\
\hline No risk subsample & 0.26 & 0.44 & $15-19$ & 42 \\
\hline Boys & 0.35 & 0.48 & $15-19$ & 160 \\
\hline Girls & 0.36 & 0.48 & $15-19$ & 177 \\
\hline \multicolumn{5}{|c|}{ Average alcohol consumption } \\
\hline Total sample & 11.07 & 21.02 & $15-19$ & 322 \\
\hline High risk subsample & 11.02 & 21.70 & $15-19$ & 28 \\
\hline No risk subsample & 10.02 & 19.19 & $15-19$ & 42 \\
\hline Boys & 15.42 & 25.81 & $15-19$ & 149 \\
\hline Girls & 7.32 & 14.82 & $15-19$ & 173 \\
\hline \multicolumn{5}{|c|}{ Autonomy } \\
\hline Total sample & 4.70 & 0.96 & $8-11$ & 353 \\
\hline High risk subsample & 4.68 & 1.09 & $8-11$ & 33 \\
\hline No risk subsample & 4.71 & 0.91 & $8-11$ & 44 \\
\hline Boys & 4.59 & 1.01 & $8-11$ & 169 \\
\hline Girls & 4.82 & 0.89 & $8-11$ & 184 \\
\hline
\end{tabular}

The psychosocial (organic) risk sample excludes individuals with organic (psychosocial) risk. 
Table 3: Estimated effects of early skills on grades in math between ages 11-15

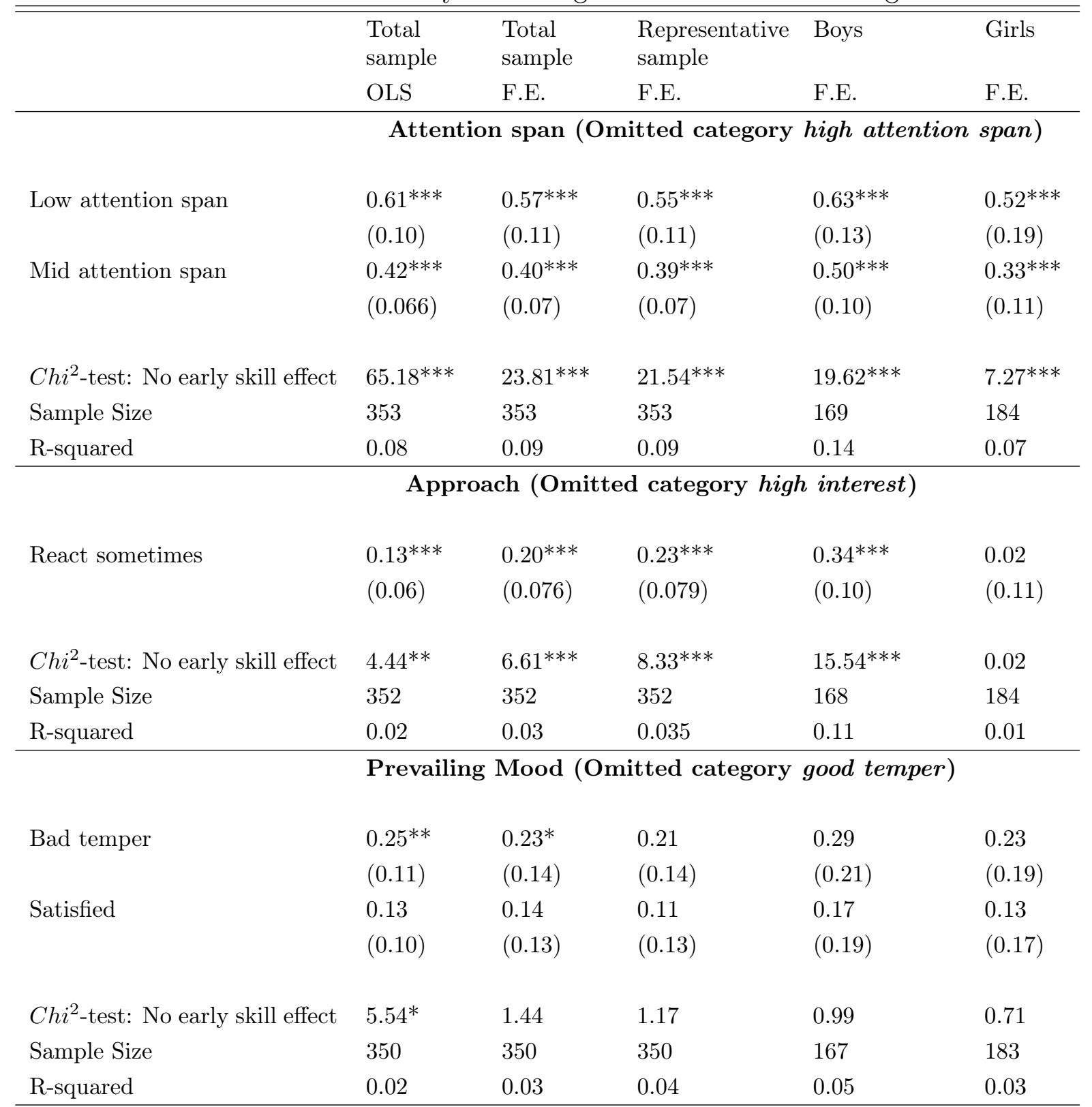

Distractibility (Omitted category easy to calm)

\begin{tabular}{llllll} 
Difficult to calm & $0.43^{* * *}$ & $0.47^{* * *}$ & $0.46^{* * *}$ & $0.44^{* *}$ & $0.49^{* *}$ \\
& $(0.11)$ & $(0.14)$ & $(0.14)$ & $(0.19)$ & $(0.22)$ \\
Adequate to calm & $0.15^{*}$ & 0.15 & 0.07 & 0.16 & 0.13 \\
& $(0.09)$ & $(0.11)$ & $(0.11)$ & $(0.16)$ & $(0.16)$ \\
Chi ${ }^{2}$-test: No early skill effect & $15.72^{* * *}$ & $5.92^{* * *}$ & $6.19^{* * *}$ & $2.71^{*}$ & $2.59^{*}$ \\
Sample Size & 348 & 348 & 348 & 166 & 182 \\
R-squared & 0.06 & 0.06 & 0.07 & 0.09 & 0.06 \\
\hline \hline
\end{tabular}

All models include a dummy variable for a single household, a dummy variable for the number of household members (from two to more than 5 members) and a dummy variable, which takes the value one, if the family composition has not changed until now. Standard Errors are in parentheses: $* * *$ significant at $1 \%, 5 \%$ and $10 \%$ level. 
Table 4: Estimated effects of early skills on grade in German between ages 11-15

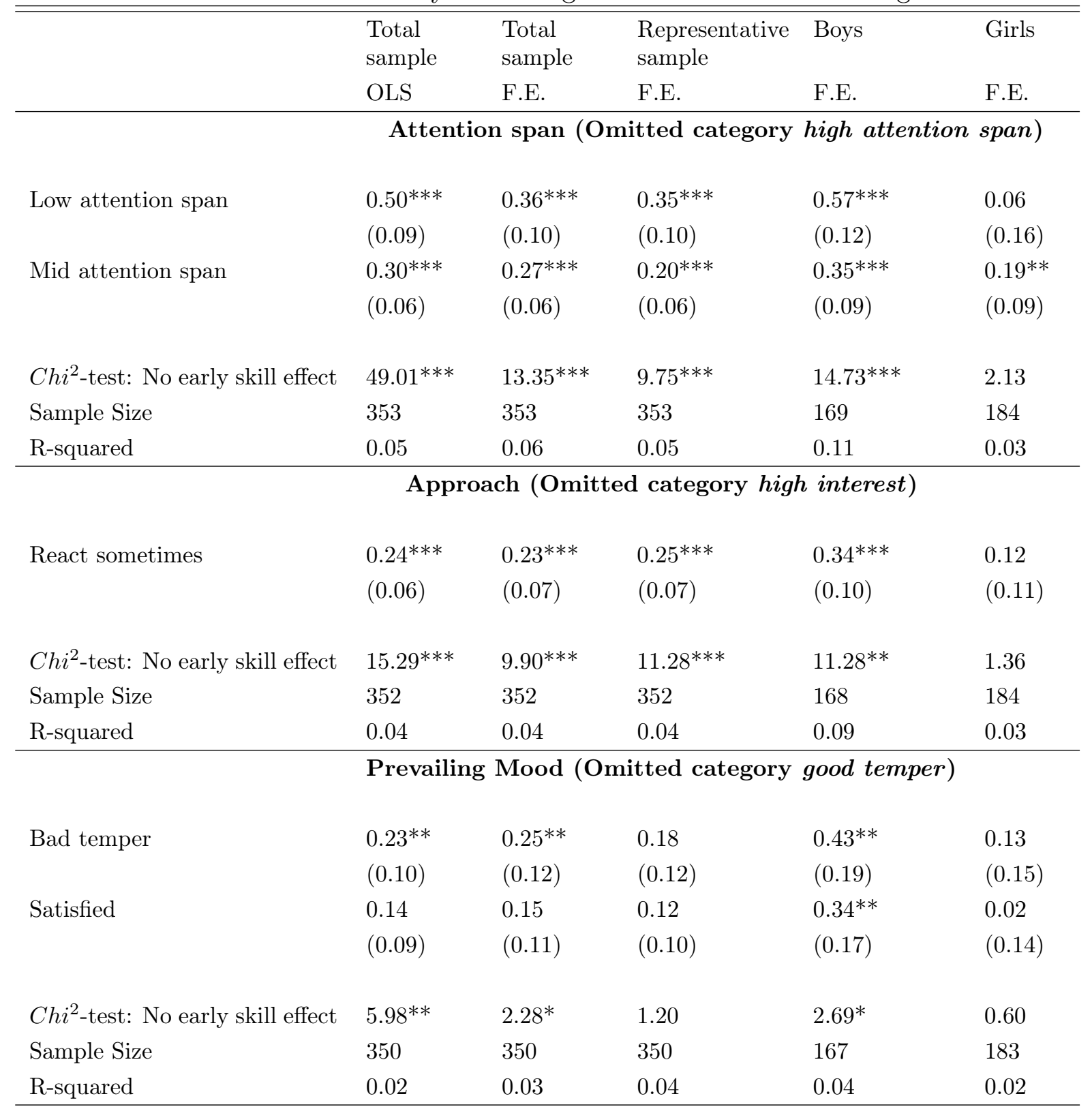

Distractibility (Omitted category easy to calm)

\begin{tabular}{llllll} 
Difficult to calm & $0.26^{* * *}$ & 0.15 & 0.11 & 0.10 & 0.18 \\
& $(0.09)$ & $(0.12)$ & $(0.12)$ & $(0.17)$ & $(0.17)$ \\
Adequate to calm & $0.18^{* *}$ & 0.09 & 0.07 & 0.16 & 0.17 \\
& $(0.08)$ & $(0.09)$ & $(0.09)$ & $(0.16)$ & $(0.13)$ \\
& & & & & \\
Chi ${ }^{2}$-test: No early skill effect & $8.28^{* *}$ & 0.88 & 0.46 & 0.25 & 0.22 \\
Sample Size & 348 & 348 & 348 & 166 & 182 \\
R-squared & 0.02 & 0.03 & 0.03 & 0.04 & 0.05 \\
\hline \hline
\end{tabular}

All models include a dummy variable for a single household, a dummy variable for the number of household members (from two to more than 5 members) and a dummy variable, which takes the value one, if the family composition has not changed until now. Standard Errors are in parentheses: ${ }^{* * *}$ significant at $1 \%, 5 \%$ and $10 \%$ level. 
Table 5: Estimated effects of early skills on delinquency between ages 15-19

\begin{tabular}{|c|c|c|c|c|c|}
\hline & $\begin{array}{l}\text { Total } \\
\text { sample }\end{array}$ & $\begin{array}{l}\text { Total } \\
\text { sample }\end{array}$ & $\begin{array}{l}\text { Representative } \\
\text { sample }\end{array}$ & Boys & Girls \\
\hline & OLS & F.E. & F.E. & F.E. & F.E. \\
\hline & \multicolumn{5}{|c|}{ Attention span (Omitted category high attention span) } \\
\hline \multirow[t]{2}{*}{ Low attention span } & $3.04^{* * *}$ & $3.24^{* * *}$ & $3.11^{* * *}$ & $4.94^{* * *}$ & 0.89 \\
\hline & $(0.52)$ & $(0.59)$ & $(0.59)$ & $(0.92)$ & $(0.74)$ \\
\hline \multirow[t]{2}{*}{ Mid attention span } & $1.88^{* * *}$ & $2.03^{* * *}$ & $2.18^{* * *}$ & $2.35^{* * *}$ & $1.69 * * *$ \\
\hline & $(0.37)$ & $(0.40)$ & $(0.41)$ & $(0.69)$ & $(0.45)$ \\
\hline$C h i^{2}$-test: No early skill effect & $48.94^{* * *}$ & $22.53^{* * *}$ & 23.03 & $16.26^{* * *}$ & $7.22^{* * *}$ \\
\hline Sample Size & 337 & 337 & 337 & 160 & 177 \\
\hline \multirow[t]{2}{*}{ R-squared } & 0.14 & 0.15 & 0.16 & 0.24 & 0.12 \\
\hline & \multicolumn{5}{|c|}{ Approach (Omitted category high interest) } \\
\hline \multirow[t]{2}{*}{ React sometimes } & $1.16^{* * *}$ & $1.39^{* * *}$ & $1.53^{* * *}$ & $2.30 * * *$ & 0.45 \\
\hline & $(0.37)$ & $(0.43)$ & $(0.44)$ & $(0.73)$ & $(0.48)$ \\
\hline$C h i^{2}$-test:No early skill effect & 9.63 & $10.46^{* * *}$ & $12.07^{* * *}$ & $9.90 * * *$ & 0.88 \\
\hline Sample Size & 337 & 337 & 337 & 160 & 177 \\
\hline \multirow[t]{2}{*}{ R-squared } & 0.04 & 0.06 & 0.07 & 0.13 & 0.04 \\
\hline & \multicolumn{5}{|c|}{ Prevailing Mood (Omitted category good temper) } \\
\hline \multirow[t]{2}{*}{ Bad temper } & -0.16 & -0.17 & 0.39 & -0.57 & -0.08 \\
\hline & $(0.68)$ & $(0.86)$ & $(0.90)$ & $(1.88)$ & $(0.89)$ \\
\hline \multirow[t]{2}{*}{ Satisfied } & 0.68 & 0.70 & 1.03 & 1.41 & -0.31 \\
\hline & $(0.62)$ & $(0.78)$ & $(0.80)$ & $(1.68)$ & $(0.82)$ \\
\hline$C h i^{2}$-test: No early skill effect & 3.81 & 1.29 & 1.15 & 2.25 & 0.10 \\
\hline Sample Size & 331 & 331 & 331 & 159 & 172 \\
\hline \multirow[t]{2}{*}{ R-squared } & 0.02 & 0.04 & 0.04 & 0.14 & 0.04 \\
\hline & \multicolumn{5}{|c|}{ Distractibility (Omitted category easy to calm) } \\
\hline \multirow[t]{2}{*}{ Difficult to calm } & 0.65 & $1.61^{*}$ & $1.80^{*}$ & $3.65^{* *}$ & -0.51 \\
\hline & $(0.71)$ & $(0.96)$ & $(1.0)$ & $(1.50)$ & $(1.15)$ \\
\hline \multirow[t]{2}{*}{ Adequate to calm } & -0.18 & 0.19 & 0.15 & 1.79 & -1.13 \\
\hline & $(0.55)$ & $(0.72)$ & $(0.74)$ & $(1.23)$ & $(0.79)$ \\
\hline$C h i^{2}$-test: No early skill effect & 1.85 & 1.79 & 2.14 & $2.95^{*}$ & 1.09 \\
\hline Sample Size & 317 & 317 & 317 & 146 & 171 \\
\hline R-squared & .02 & 0.07 & 0.09 & 0.20 & 0.07 \\
\hline
\end{tabular}

All models include a dummy variable for a single household, a dummy variable for the number of household members (from two to more than 5 members) and a dummy variable, which takes the value one, if the family composition has not changed until now. Standard Errors are in parentheses: $* * *$ significant at $1 \%, 5 \%$ and $10 \%$ level. 
Table 6: Estimated effects of early skills on smoking between ages 15-19

\begin{tabular}{|c|c|c|c|c|c|}
\hline & $\begin{array}{l}\text { Total } \\
\text { sample }\end{array}$ & $\begin{array}{l}\text { Total } \\
\text { sample }\end{array}$ & $\begin{array}{l}\text { Representative } \\
\text { sample }\end{array}$ & Boys & Girls \\
\hline & OLS & F.E. & F.E. & F.E. & F.E. \\
\hline & \multicolumn{5}{|c|}{ Attention span (Omitted category high attention span) } \\
\hline \multirow[t]{2}{*}{ Low attention span } & $0.11^{* *}$ & $0.13^{* *}$ & $0.15^{* *}$ & $0.31^{* * *}$ & -0.12 \\
\hline & $(0.05)$ & $(0.06)$ & $(0.06)$ & $(0.08)$ & $(0.10)$ \\
\hline \multirow[t]{2}{*}{ Mid attention span } & $0.09 * *$ & $0.11^{* *}$ & $0.13^{* * *}$ & $0.21^{* * *}$ & 0.02 \\
\hline & $(0.04)$ & $(0.04)$ & $(0.04)$ & $(0.06)$ & $(0.06)$ \\
\hline$C h i^{2}$-test: No early skill effect & $8.64^{* *}$ & $4.19^{* *}$ & $5.68^{* * *}$ & $10.15^{* * *}$ & 0.86 \\
\hline Sample Size & 337 & 337 & 337 & 160 & 177 \\
\hline \multirow[t]{2}{*}{ R-squared } & 0.05 & 0.09 & 0.11 & 0.21 & 0.07 \\
\hline & \multicolumn{5}{|c|}{ Approach (Omitted category high interest) } \\
\hline \multirow[t]{2}{*}{ React sometimes } & $0.07^{*}$ & $0.10^{* *}$ & $0.10^{* *}$ & $0.15^{* *}$ & 0.04 \\
\hline & $(0.035)$ & $(0.04)$ & $(0.046)$ & $(0.06)$ & $(0.06)$ \\
\hline$C h i^{2}$-test: No early skill effect & $3.67^{*}$ & $5.20^{* *}$ & $5.01^{* *}$ & $5.71^{* *}$ & 0.52 \\
\hline Sample Size & 337 & 337 & 337 & 160 & 177 \\
\hline \multirow[t]{2}{*}{ R-squared } & 0.04 & 0.08 & 0.09 & 0.13 & 0.07 \\
\hline & \multicolumn{5}{|c|}{ Prevailing Mood (Omitted category good temper) } \\
\hline \multirow[t]{2}{*}{ Bad temper } & 0.04 & $0.19^{* *}$ & $0.16^{*}$ & -0.03 & $0.26^{* *}$ \\
\hline & $(0.06)$ & $(0.09)$ & $(0.097)$ & $(0.18)$ & $(0.11)$ \\
\hline \multirow[t]{2}{*}{ Satisfied } & 0.07 & 0.10 & 0.09 & -0.06 & 0.13 \\
\hline & $(0.06)$ & $(0.08)$ & $(0.09)$ & $(0.16)$ & $(0.10)$ \\
\hline$C h i^{2}$-test: No early skill effect & 1.79 & 2.28 & 1.45 & 0.11 & $2.67^{*}$ \\
\hline Sample Size & 331 & 331 & 331 & 159 & 172 \\
\hline \multirow[t]{2}{*}{ R-squared } & 0.02 & 0.07 & 0.09 & 0.12 & 0.11 \\
\hline & \multicolumn{5}{|c|}{ Distractibility (Omitted category easy to calm) } \\
\hline \multirow[t]{2}{*}{ Difficult to calm } & $-0.14^{* *}$ & -0.13 & -0.12 & -0.14 & -0.11 \\
\hline & $(0.06)$ & $(0.09)$ & $(0.09)$ & $(0.13)$ & $(0.15)$ \\
\hline \multirow[t]{2}{*}{ Adequate to calm } & $-0.11^{* *}$ & $-0.14^{* *}$ & $-0.15^{* *}$ & -0.12 & $-0.17^{*}$ \\
\hline & $(0.05)$ & $(0.07)$ & $(0.07)$ & $(0.11)$ & $(0.10)$ \\
\hline$C h i^{2}$-test: No early skill effect & $6.31^{* *}$ & 2.14 & 2.22 & 0.73 & 1.52 \\
\hline Sample Size & 317 & 317 & 317 & 146 & 171 \\
\hline R-squared & 0.05 & 0.10 & 0.11 & 0.07 & 0.18 \\
\hline
\end{tabular}

All models include a dummy variable for a single household, a dummy variable for the number of household members (from two to more than 5 members) and a dummy variable, which takes the value one, if the family composition has not changed until now. Standard Errors are in parentheses: ***significant at $1 \%, 5 \%$ and $10 \%$ level. 
Table 7: Estimated effects of early skills on alcohol consumption between ages 15-19

\begin{tabular}{|c|c|c|c|c|c|}
\hline & $\begin{array}{l}\text { Total } \\
\text { sample }\end{array}$ & $\begin{array}{l}\text { Total } \\
\text { sample }\end{array}$ & $\begin{array}{l}\text { Representative } \\
\text { sample }\end{array}$ & Boys & Girls \\
\hline & OLS & F.E. & F.E. & F.E. & F.E. \\
\hline & \multicolumn{5}{|c|}{ Attention span (Omitted Category high attention span) } \\
\hline \multirow[t]{2}{*}{ Low attention span } & $12.73^{* * *}$ & $22.04^{* * *}$ & $22.77^{* * *}$ & $33.5^{* * *}$ & $8.22^{* *}$ \\
\hline & $(2.48)$ & $(3.42)$ & $(3.45)$ & $(5.50)$ & $(3.70)$ \\
\hline \multirow[t]{2}{*}{ Mid attention span } & $9.08^{* * *}$ & $13.66^{* * *}$ & $11.30^{* * *}$ & $19.54^{* * *}$ & $7.57^{* * *}$ \\
\hline & $(1.82)$ & $(2.31)$ & $(2.39)$ & $(4.13)$ & $(2.25)$ \\
\hline$C h i^{2}$-test: No early skill effect & $40.66^{* * *}$ & $31.22^{* * *}$ & $27.49^{* * *}$ & $23.51^{* * *}$ & $7.20^{* * *}$ \\
\hline Sample Size & 322 & 322 & 322 & 149 & 173 \\
\hline \multirow[t]{2}{*}{ R-squared } & 0.16 & 0.20 & 0.18 & 0.33 & 0.10 \\
\hline & \multicolumn{5}{|c|}{ Approach (Omitted category high interest) } \\
\hline \multirow[t]{2}{*}{ React sometimes } & $3.38^{* *}$ & $7.90^{* * *}$ & $8.89^{* * *}$ & $10.27^{* *}$ & $5.06^{* *}$ \\
\hline & $(1.69)$ & $(2.54)$ & $(2.61)$ & $(4.63)$ & $(2.37)$ \\
\hline$C h i^{2}$-test: No early skill effect & $3.99^{* *}$ & $9.65^{* * *}$ & $11.63^{* * *}$ & $4.91^{* *}$ & $4.58^{* *}$ \\
\hline Sample Size & 322 & 322 & 322 & 149 & 173 \\
\hline \multirow[t]{2}{*}{ R-squared } & 0.03 & 0.07 & 0.07 & 0.13 & 0.05 \\
\hline & \multicolumn{5}{|c|}{ Prevailing Mood (Omitted category good temper) } \\
\hline \multirow[t]{2}{*}{ Bad temper } & 0.72 & 3.64 & 4.08 & -6.21 & 5.41 \\
\hline & $(3.17)$ & $(5.47)$ & $(5.83)$ & $(13.46)$ & $(4.43)$ \\
\hline \multirow[t]{2}{*}{ Satisfied } & 0.59 & 3.62 & 5.56 & -2.0 & 1.85 \\
\hline & $(2.89)$ & $(4.93)$ & $(5.19)$ & $(12.03)$ & $(4.04)$ \\
\hline$C h i^{2}$-test: No early skill effect & 0.05 & 0.28 & 0.59 & 0.20 & 0.90 \\
\hline Sample Size & 318 & 318 & 318 & 149 & 169 \\
\hline R-squared & 0.007 & 0.03 & 0.04 & 0.10 & 0.07 \\
\hline
\end{tabular}

Distractibility (Omitted category easy to calm)

\begin{tabular}{llllll} 
Difficult to calm & 1.24 & $11.60^{* *}$ & $15.10^{* * *}$ & $27.10^{* * *}$ & -6.95 \\
& $(2.89)$ & $(5.43)$ & $(5.94)$ & $(9.20)$ & $(5.45)$ \\
Adequate to calm & -1.19 & 5.15 & 5.58 & $14.73^{* *}$ & -4.17 \\
& $(2.26)$ & $(4.06)$ & $(4.40)$ & $(7.51)$ & $(3.73)$ \\
& & & & & \\
Chi ${ }^{2}$-test: No early skill effect & 1.01 & 2.28 & $3.26^{* *}$ & $4.34^{* *}$ & 0.96 \\
Sample Size & 306 & 306 & 306 & 139 & 167 \\
R-squared & 0.01 & 0.07 & 0.09 & 0.18 & 0.07 \\
\hline \hline
\end{tabular}

All models include a dummy variable for a single household, a dummy variable for the number of household members (from two to more than 5 members) and a dummy variable, which takes the value one, if the family composition has not changed until now. Standard Errors are in parentheses: ${ }^{* * *}$ significant at $1 \%, 5 \%$ and $10 \%$ level. 
Table 8: Estimated effects of early skills on autonomy between ages 8-11

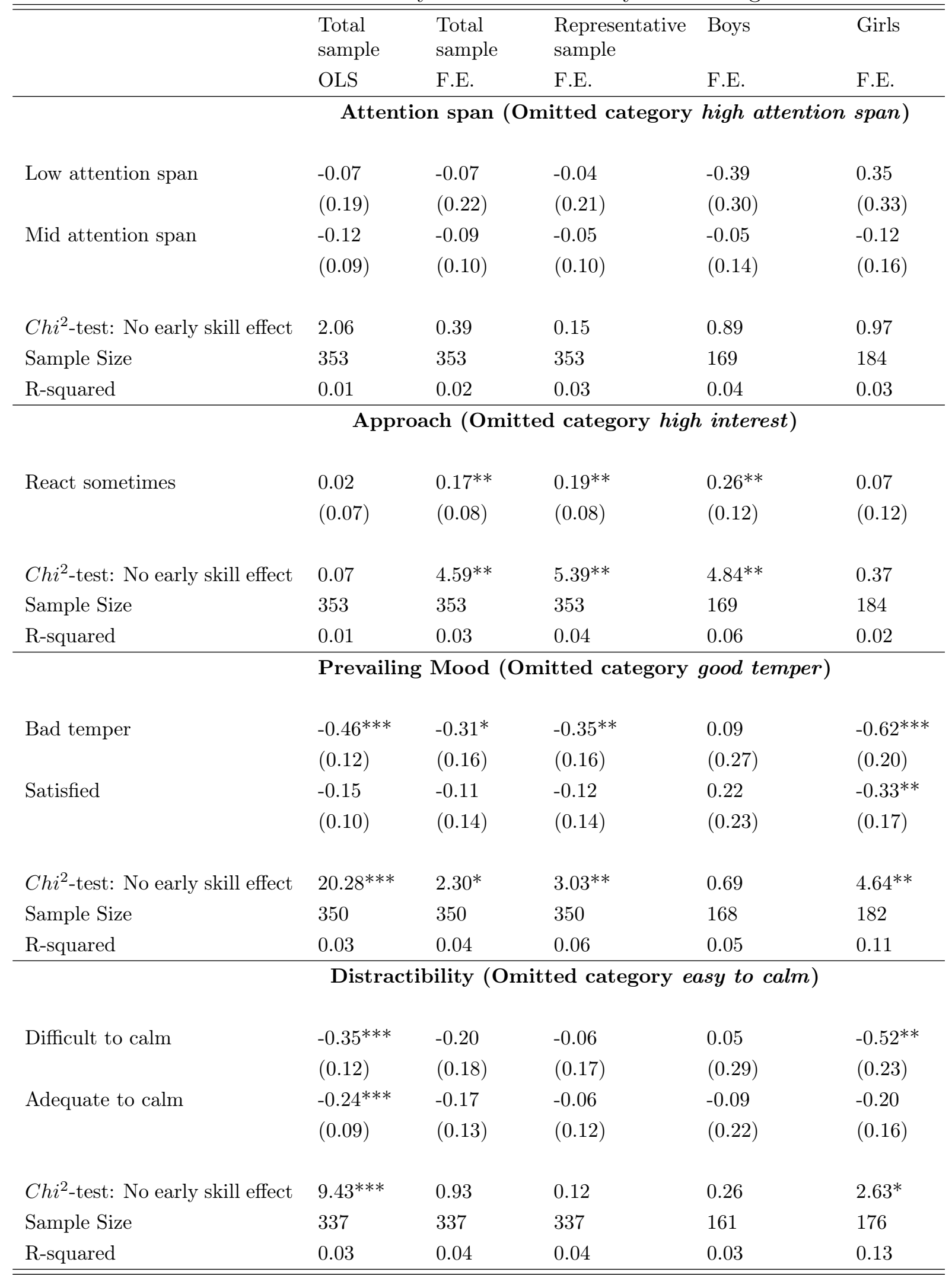

All models include a dummy variable for a single household, a dummy variable for the number of household members (from two to more than 5 members) and a dummy variable, which takes the value one, if the family composition has not changed until now. Standard Errors are in parentheses: $* * *$ significant at $1 \%, 5 \%$ and $10 \%$ level. 
Table 9: FE models of early skills on grades in math and German

\begin{tabular}{|c|c|c|c|c|}
\hline & \multicolumn{2}{|c|}{ grade math } & \multicolumn{2}{|c|}{ grade German } \\
\hline & $\begin{array}{l}\text { Psycho-social } \\
\text { subsample }\end{array}$ & $\begin{array}{l}\text { Organic } \\
\text { subsample }\end{array}$ & $\begin{array}{l}\text { Psycho-social } \\
\text { subsample }\end{array}$ & $\begin{array}{l}\text { Organic } \\
\text { subsample }\end{array}$ \\
\hline & \multicolumn{4}{|c|}{ Attention span (Omitted category high attention span) } \\
\hline \multirow[t]{2}{*}{ Low attention span } & $0.48^{* *}$ & $1.07^{* * *}$ & 0.03 & $0.52^{* *}$ \\
\hline & $(0.24)$ & $(0.27)$ & $(0.20)$ & $(0.25)$ \\
\hline \multirow[t]{2}{*}{ Mid attention span } & $0.39^{* * *}$ & $0.50^{* * *}$ & 0.16 & $0.48^{* * *}$ \\
\hline & $(0.17)$ & $(0.15)$ & $(0.14)$ & $(0.14)$ \\
\hline$C h i^{2}$-test: No early skill effect & $3.91^{* * *}$ & $12.42^{* * *}$ & 0.63 & $7.52^{* * *}$ \\
\hline Sample Size & 77 & 77 & 77 & 77 \\
\hline \multirow[t]{2}{*}{ R-squared } & 0.07 & 0.20 & 0.04 & 0.14 \\
\hline & \multicolumn{4}{|c|}{ Approach (Omitted category high interest) } \\
\hline \multirow[t]{2}{*}{ React sometimes } & 0.26 & $0.28^{*}$ & 0.24 & 0.14 \\
\hline & $(0.18)$ & $(0.16)$ & $(0.16)$ & $(0.17)$ \\
\hline$C h i^{2}$-test: No early skill effect & 1.97 & $2.97^{*}$ & 2.47 & 0.64 \\
\hline Sample Size & 77 & 77 & 77 & 77 \\
\hline \multirow[t]{2}{*}{ R-squared } & 0.06 & 0.07 & 0.06 & 0.08 \\
\hline & \multicolumn{4}{|c|}{ Prevailing Mood (Omitted category good temper) } \\
\hline \multirow[t]{2}{*}{ Bad temper } & -0.07 & 0.46 & -0.07 & 0.33 \\
\hline & $(0.30)$ & $(0.29)$ & $(0.19)$ & $(0.27)$ \\
\hline \multirow[t]{2}{*}{ Satisfied } & -0.02 & 0.32 & 0.06 & 0.20 \\
\hline & $(0.27)$ & $(0.26)$ & $(0.21)$ & $(0.24)$ \\
\hline$C h i^{2}$-test: No early skill effect & 0.04 & 1.21 & 0.36 & 0.64 \\
\hline Sample Size & 77 & 77 & 77 & 77 \\
\hline \multirow[t]{2}{*}{ R-squared } & 0.02 & 0.11 & 0.05 & 0.08 \\
\hline & \multicolumn{4}{|c|}{ Distractibility (Omitted category easy to calm) } \\
\hline \multirow[t]{2}{*}{ Difficult to calm } & 0.33 & 0.35 & -0.07 & 0.24 \\
\hline & $(0.31)$ & $(0.30)$ & $(0.23)$ & $(0.27)$ \\
\hline \multirow[t]{2}{*}{ Adequate to calm } & 0.02 & 0.15 & 0.19 & 0.05 \\
\hline & $(0.24)$ & $(0.23)$ & $(0.18)$ & $(0.20)$ \\
\hline$C h i^{2}$-test: No early skill effect & 0.76 & 0.68 & 1.05 & 0.50 \\
\hline Sample Size & 77 & 77 & 77 & 77 \\
\hline R-squared & 0.09 & 0.16 & 0.11 & 0.07 \\
\hline
\end{tabular}

All models include a dummy variable for a single household, a dummy variable for the number of household members (from two to more than 5 members) and a dummy variable, which takes the value one, if the family composition has not changed until now. Standard Errors are in parentheses: $* * *$ significant at $1 \%, 5 \%$ and $10 \%$ level. 
Table 10: FE models of early skills on smoking and alcohol use

\begin{tabular}{lllll}
\hline \hline & \multicolumn{2}{c}{ smoking } & \multicolumn{2}{c}{ average alcohol use } \\
& $\begin{array}{l}\text { Psycho-social } \\
\text { subsample }\end{array}$ & $\begin{array}{l}\text { Organic } \\
\text { subsample }\end{array}$ & $\begin{array}{l}\text { Psycho-social } \\
\text { subsample }\end{array}$ & $\begin{array}{l}\text { Organic } \\
\text { subsample }\end{array}$ \\
\hline & Attention span & (Omitted category high attention span) \\
Low attention span & $0.23^{*}$ & $-1.38 \mathrm{e}-30$ & $27.36^{* * *}$ & 13.68 \\
& $(0.14)$ & $(0.17)$ & $(7.53)$ & $(8.66)$ \\
Mid attention span & $0.30^{* * *}$ & 0.03 & $7.85^{* * *}$ & $20.89^{* * *}$ \\
& $(0.10)$ & $(0.10)$ & $(5.42)$ & $(4.97)$ \\
Chi ${ }^{2}$-test: No early skill effect & $5.63^{* * *}$ & 0.04 & $7.01^{* * *}$ & $10.07^{* * *}$ \\
Sample Size & 73 & 75 & 72 & 72 \\
R-squared & 0.29 & 0.16 & 0.21 & 0.25 \\
\hline
\end{tabular}

Approach (Omitted category high interest)

\begin{tabular}{|c|c|c|c|c|}
\hline React sometimes & $\begin{array}{l}0.12 \\
(0.10)\end{array}$ & $\begin{array}{l}0.11 \\
(0.09)\end{array}$ & $\begin{array}{l}9.89^{*} \\
(5.54)\end{array}$ & $\begin{array}{l}12.31^{* *} \\
(5.22)\end{array}$ \\
\hline$C h i^{2}$-test: No early skill effect & 1.49 & 1.36 & $3.19^{*}$ & $5.56^{* *}$ \\
\hline Sample Size & 73 & 75 & 72 & 72 \\
\hline R-squared & 0.19 & 0.17 & 0.09 & 0.09 \\
\hline & \multicolumn{4}{|c|}{ Prevailing Mood (Omitted category good temper) } \\
\hline \multirow[t]{2}{*}{ Bad temper } & -0.10 & 0.28 & -5.40 & 15.92 \\
\hline & $(0.21)$ & $(0.23)$ & $(13.05)$ & $(14.74)$ \\
\hline \multirow[t]{2}{*}{ Satisfied } & -0.10 & 0.08 & 5.43 & 9.36 \\
\hline & $(0.19)$ & $(0.19)$ & $(12.25)$ & $(11.96)$ \\
\hline$C h i^{2}$-test: No early skill effect & 0.15 & 1.21 & 0.58 & 0.60 \\
\hline Sample Size & 73 & 74 & 72 & 72 \\
\hline \multirow[t]{2}{*}{ R-squared } & 0.25 & 0.21 & 0.04 & 0.04 \\
\hline & \multicolumn{4}{|c|}{ Distractibility (Omitted category easy to calm) } \\
\hline \multirow[t]{2}{*}{ Difficult to calm } & -0.03 & -0.23 & $34.69^{* * *}$ & 9.73 \\
\hline & $(0.19)$ & $(0.22)$ & $(12.24)$ & $(12.82)$ \\
\hline \multirow[t]{2}{*}{ Adequate to calm } & -0.06 & -0.21 & 12.90 & 9.14 \\
\hline & $(0.14)$ & $(0.16)$ & $(9.34)$ & $(9.31)$ \\
\hline$C h i^{2}$-test: No early skill effect & 0.09 & 0.94 & $4.02^{* *}$ & 0.50 \\
\hline Sample Size & 72 & 69 & 71 & 67 \\
\hline R-squared & 0.16 & 0.30 & 0.19 & 0.04 \\
\hline
\end{tabular}

All models include a dummy variable for a single household, a dummy variable for the number of household members (from two to more than 5 members) and a dummy variable, which takes the value one, if the family composition has not changed until now. Standard Errors are in parentheses: $* * *$ significant at $1 \%, 5 \%$ and $10 \%$ level. 
Table 11: FE models of early skills on delinquency and autonomy

\begin{tabular}{|c|c|c|c|c|}
\hline & \multicolumn{2}{|c|}{ delinquency } & \multicolumn{2}{|c|}{ autonomy } \\
\hline & $\begin{array}{l}\text { Psycho-social } \\
\text { subsample }\end{array}$ & $\begin{array}{l}\text { Organic } \\
\text { subsample }\end{array}$ & $\begin{array}{l}\text { Psycho-social } \\
\text { subsample }\end{array}$ & $\begin{array}{l}\text { Organic } \\
\text { subsample }\end{array}$ \\
\hline & \multicolumn{4}{|c|}{ Attention span (Omitted category high attention span) } \\
\hline \multirow[t]{2}{*}{ Low attention span } & $2.50 * *$ & $2.89^{* *}$ & -0.47 & 0.06 \\
\hline & $(1.27)$ & $(1.47)$ & $(0.42)$ & $(0.63)$ \\
\hline \multirow[t]{2}{*}{ Mid attention span } & $2.83^{* * *}$ & $1.97^{* *}$ & 0.02 & -0.33 \\
\hline & $(0.91)$ & $(0.84)$ & $(0.23)$ & $(0.24)$ \\
\hline$C h i^{2}$-test: No early skill effect & $5.97^{* * *}$ & $4.64^{* *}$ & 0.63 & 0.97 \\
\hline Sample Size & 73 & 75 & 77 & 77 \\
\hline \multirow[t]{2}{*}{ R-squared } & 0.20 & 0.17 & 0.11 & 0.15 \\
\hline & \multicolumn{4}{|c|}{ Approach (Omitted category high interest) } \\
\hline \multirow[t]{2}{*}{ React sometimes } & $1.86^{* *}$ & $1.58^{*}$ & 0.0001 & 0.17 \\
\hline & $(0.91)$ & $(0.84)$ & $(0.18)$ & $(0.14)$ \\
\hline$C h i^{2}$-test: No early skill effect & $4.16^{* *}$ & $3.54^{*}$ & 0.00 & 1.45 \\
\hline Sample Size & 73 & 75 & 77 & 77 \\
\hline \multirow[t]{2}{*}{ R-squared } & 0.11 & 0.09 & 0.09 & 0.14 \\
\hline & \multicolumn{4}{|c|}{ Prevailing Mood (Omitted category good temper) } \\
\hline \multirow[t]{2}{*}{ Bad temper } & -0.87 & 1.77 & $-0.80^{* *}$ & 0.09 \\
\hline & $(1.92)$ & $(1.80)$ & $(0.34)$ & $(0.36)$ \\
\hline \multirow[t]{2}{*}{ Satisfied } & 1.08 & 1.94 & -0.46 & 0.35 \\
\hline & $(1.80)$ & $(1.46)$ & $(0.28)$ & $(0.31)$ \\
\hline$C h i^{2}$-test: No early skill effect & 0.88 & 0.89 & $2.87^{*}$ & 1.35 \\
\hline Sample Size & 73 & 74 & 77 & 77 \\
\hline \multirow[t]{2}{*}{ R-squared } & 0.08 & 0.13 & 0.24 & 0.24 \\
\hline & \multicolumn{4}{|c|}{ Distractibility (Omitted category easy to calm) } \\
\hline \multirow[t]{2}{*}{ Difficult to calm } & 2.88 & 0.83 & 0.27 & -0.38 \\
\hline & $(1.85)$ & $(1.81)$ & $(0.36)$ & $(0.38)$ \\
\hline \multirow[t]{2}{*}{ Adequate to calm } & -0.52 & 0.43 & 0.21 & -0.24 \\
\hline & $(1.41)$ & $(1.32)$ & $(0.25)$ & $(0.30)$ \\
\hline$C h i^{2}$-test: No early skill effect & 2.17 & 0.11 & 0.43 & 0.53 \\
\hline Sample Size & 72 & 69 & 76 & 73 \\
\hline R-squared & 0.14 & 0.13 & 0.26 & 0.28 \\
\hline
\end{tabular}

All models include a dummy variable for a single household, a dummy variable for the number of household members (from two to more than 5 members) and a dummy variable, which takes the value one, if the family composition has not changed until now. Standard Errors are in parentheses: $* * *$ significant at $1 \%, 5 \%$ and $10 \%$ level. 